\title{
Standing Out or Blending In: Academic Libraries in the Crowded Informal Learning Space Ecosystem
}

\section{Erica Lynn DeFrain, Jennifer Thoegersen, and Miyoung Hong}

\begin{abstract}
As more campus locations establish intentional informal learning spaces, what, if anything, is the unique value of these spaces within the physical academic library? Using mixed methods, this study examines the relationship between students' use, satisfaction, and productivity needs at five discrete locations at a large public university. Findings from unobtrusive observations, student surveys, and semistructured focus groups reveal an interconnected ecosystem of campus informal learning spaces in which the academic library is prominently situated, providing guidance for those making decisions around the availability and design of library learning spaces.
\end{abstract}

\section{Introduction}

Academic libraries, long heralded as sacred spaces for deep reflection and quiet study, witnessed a dramatic shift away from the communal toward the sociocollaborative when the learning commons model became commonplace. Tied to the digital revolution, which greatly reduced the need for close proximity to physical collections, librarians and administrators replaced spaces once filled with books with student-centered social spaces, replete with comfortable furnishings and coffee shop environments. ${ }^{1}$ The success of these spaces, measured by the drastic increase in gate counts of the libraries in which they were built, resulted in a devaluing of quiet spaces that was fueled by assumptions regarding students' learning needs in the twenty-first century. At the same time, the success of these new library spaces likely contributed to the more intentional development of commons spaces in campus locations well outside the library. ${ }^{2}$ These new informal learning spaces (ILSs) are overtly derivative of the modern socialness at the root of the learning commons model, thus raising questions of how students navigate this increasingly homogenous learning space ecosystem, and how libraries can best support students' learning space needs.

At the University of Nebraska-Lincoln, a public land-grant research university with more than 25,000 students, recent renovation and construction projects have focused extensively

\footnotetext{
*Erica Lynn DeFrain is Associate Professor and Social Sciences Librarian at the University of Nebraska-Lincoln; email: edefrain2@unl.edu. Jennifer Thoegersen is a Ph.D. candidate in the Department of Archivistics, Library and Information Science at Oslo Metropolitan University and a Visiting Adjunct Research Associate at the University of Nebraska-Lincoln Libraries; email: jennifer.thoegersen@oslomet.no. Miyoung Hong is a Senior Lecturer in Interior Design at Indiana University-Bloomington; email:miyhong@iu.edu. @2022 Erica Lynn DeFrain, Jennifer Thoegersen, and Miyoung Hong, Attribution-NonCommercial (https://creativecommons.org/licenses/by-nc/4.0/) CC BY-NC.
} 
on creating ILSs that typify this trend. In 2016, the main academic library opened a learning commons, which was created by renovating approximately 30,000 square feet of space that once housed more than 300,000 books. Instantly popular, the bustling nature of the learning commons stands in direct contrast to the more secluded environs of the adjoining library. Soon after the opening of the learning commons, the university vastly expanded the number of similar nonclassroom study spaces. The student union underwent a large-scale renovation, which supplanted some of its more traditional recreational areas with spaces for learning and group work. The university also unveiled two brand-new buildings, the College of Business and the College of Nursing. Both buildings were envisioned as fully contained academic spaces for their students, with classrooms, cafes, faculty offices, academic support services, and numerous ILSs spread across multiple floors throughout the buildings.

While other ILSs are on the campus, the introduction of these highly visible projects nearly quadrupled the ILS seating capacity and ultimately gifted the students with choice. Where previously students' study locations were largely limited to home, the library, or an off-campus locale, they suddenly had numerous, very similar, options all within close proximity to one another.

With the abrupt influx of these new ILSs, understanding their use is important not only to a university seeking to best meet the learning needs of its students, but also to an academic library looking to establish or maintain a singular identity. Therefore, the guiding question for this study is: As more campus locations develop intentional informal learning spaces, what, if anything, is the unique value of these spaces within the physical academic library? To address this question, this study used observations, surveys, and focus groups to examine students' use, satisfaction, and self-perceived productivity at five distinct ILSs.

\section{Literature Review}

There is not one standardized definition for what constitutes an informal learning space. ${ }^{3}$ Most descriptions identify them broadly within both physical and virtual realms, ${ }^{4}$ with some applying more limiting operationalizations. Many have adopted the descriptor of ILSs being "nondiscipline specific," ${ }^{5}$ though others have noted their appearance within departmental or college buildings. ${ }^{6}$ Academic libraries are frequently placed at the center of ILS research, ${ }^{7}$ although there is disagreement over whether the learning activities occurring within academic library spaces should be considered informal. ${ }^{8}$ Bennett omitted the term informal from his study on campus learning spaces, but he did include a wide range of nonclassroom campus locations in his investigation into whether they supported various intentional learning behaviors. ${ }^{9}$ Altimare and Sheridan used the descriptor nonclassroom spaces interchangeably with ILSs. ${ }^{10}$ For the purpose of this study, ILSs are defined simply as nonclassroom commons locations in which self-directed learning is a primary purpose.

Informal learning spaces have been examined for decades, with informal and formal learning settings viewed as being complementary to one another. ${ }^{11}$ Recognizing that students' learning and engagement with learning materials occurs at greater rates outside the formal classroom,$^{12}$ many researchers have been inspired to consider more closely the built environment's relationship to learning, especially with regard to effect, behavior, and cognition. ${ }^{13}$ Academic libraries have figured prominently within the empirical ILS literature, particularly as more libraries have developed information and learning commons. The student-centered onus of the commons design strategically assisted libraries looking for ways to retain their 
notable role within higher education. While it is still unclear how these new social spaces contribute to students' use of library resources and services, ${ }^{14}$ the boost in gate counts and overflowing capacity have provided many institutions a rapid measure of success. ${ }^{15}$

Single case studies of libraries or learning commons feature heavily in the literature examining the relationship between ILSs and the students who use them. In Badia's review of 55 such studies published since 1990, she characterized them as largely employing mixed methods, with most adopting the ethnographic traits of survey, observation, and interview since the release of Foster and Gibbons's seminal study. ${ }^{16}$ Satisfaction is a considerable if not primary metric for many of these studies, ${ }^{17}$ with researchers only recently establishing a strong positive association between this psychological concept and behavioral learning outcomes. ${ }^{18}$ Despite numerous guides, toolkits, and measures, ${ }^{19}$ no one instrument or method has been accepted as appropriately reliable or valid, and most researchers continue to develop their own protocols. ${ }^{20}$

Many of the library ILS studies reveal a strong tension over their appropriate atmosphere between the researchers evaluating them and the students inhabiting them. The learning commons model heavily favors active collaboration to mirror the active and group learning activities occurring in the classrooms, ${ }^{21}$ but the busyness of these spaces is often perceived as disruptive by the students. ${ }^{22}$ A number of researchers have predicted an inevitable increase in the desirability of this environment, ${ }^{23}$ but more have asserted an obligation to meet students' current needs. ${ }^{24}$

Primary critiques of the literature fall under methodological or conceptual categories. In Badia's review, she determined that the majority of findings were severely inhibited due to issues surrounding reproducibility, reliability, and validity. ${ }^{25}$ She concluded that "a space assessment that incorporates multiple research methods is only as strong as the rigorousness of each individual method that contributed to the final set of results." ${ }^{26}$ Berman asserted that these studies rely too heavily on quantitative methods that are incapable of revealing the complexity of students' learning needs. ${ }^{27}$ She also challenged overly prescriptive environments - what she called "architectural determinism" - as perpetuating practices of "exclusion and marginalization." ${ }^{28}$ Rather than focusing exclusively on the students in the spaces, she suggested that more work should be done to identify and remove barriers that might be keeping others out.

There are a small number of multisite studies juxtaposing library learning spaces within the broader campus context. Where Bennett's holistic evaluation of learning spaces detailed a "near mono-culture of learning and space" ${ }^{29}$ that lacked the variance needed to support the full range of learning needs on his campus, the uniqueness of quiet library atmospheres is at the forefront of others. ${ }^{30}$ May \& Swabey examined students' behaviors and connections to space in five Canadian academic libraries and defined the library's unique contribution to ILSs according to four categories: resources; quiet spaces; behavior enforcement; and communal study atmosphere. ${ }^{31}$ This unique feature of quiet atmosphere enforcement was also apparent in Walton and Cunningham's study, in which a small majority of respondents had come to the library for the quiet environment and appreciated staff enforcement of this element. ${ }^{32}$ Hunter and Cox proposed a "model of zengagement" emphasizing students' high regard for background atmosphere and asserted that libraries should prioritize "warm, friendly, and homely spaces" above all others. ${ }^{33}$ Finally, when contemplating whether a "coffee house environment" should eventually supplant the quieter study spaces within libraries, Deng et 
al. concluded that students preferred studying in the libraries because they allowed them to "carry out their learning in solitude with silence." 34

The review of the literature reveals an expansive portrait of ILS assessment techniques and findings, yet numerous questions and avenues for exploration remain. What these studies have not yet accomplished is a contextualized, comparative understanding of the social and quiet environments of the academic library within the broader ILS ecosystem, particularly one that considers students' needs and space choices in an abundant and increasingly homogenous learning space landscape.

\section{Methodology}

Informed by the participatory design approach and "multi-fold data collection model" proposed by Deed and Alterator, ${ }^{35}$ this study's use of multiple-case study design reveals the unique and shared contributions of ILSs across five discrete campus locations. Following a sequential explanatory study design, quantitative data were first gathered via field observations and a survey of students in the spaces. After preliminary analyses, qualitative data were then gathered through focus groups to provide more robust insight into quantitative findings. ${ }^{36}$ Using this method, the study underwent an iterative process of refinement and reflection for including the lived experience into the assessment. ${ }^{37}$

Nitecki and Simpson's theoretical framework for library spaces also guided this study, which posits that the higher education context and physical design of the built environment influences the individual student. ${ }^{38}$ The built environment, by satisfying psychological needs and promoting productivity and focus, can influence individual behaviors and cognitive functioning. ${ }^{39}$ Ultimately, for an informal learning space to be successful, it must satisfy the affective and emotional conditions in which learning can occur.

\section{Site Selection}

The five sites examined in this study were selected through criterion sampling, ${ }^{40}$ to represent ubiquitous campus locations that are either viewed as a common good (Library South, Learning Commons, Union) or disciplinary-oriented (Colleges of Business and Nursing) (see table 1). Each of the sites is located on the main campus within walking distance from one another and contains ILSs with relatively large public seating capacities. All of the sites had been constructed or undergone extensive renovation within two years prior to data collection, except for the south building of the academic library. This location was included to contrast students' use of these more modern spaces with those of a traditional library environment (that is, spaces in which stacks dominate). Expanding vertically across six levels, the south building's stacks integrate more than 100 individual study carrels among a few hundred thousand books. The College of Business and College of Nursing sites were chosen to understand the relationship these disciplinary spaces have with the common good settings of the academic library and student union.

\section{Data Collection and Analysis: Observation and Survey}

Data for this study were collected beginning in January 2018 and concluding in April 2019. The Learning Commons was the first site studied, ${ }^{41}$ and lessons learned resulted in minor changes to simplify and improve data collection at the remaining sites. An identical protocol was followed at each location, with data being gathered in three consecutive stages: field 
observations, survey recruitment, and focus groups. Under close supervision by the project's principal investigators, observation and survey data were collected by a team of undergraduate student research assistants who received human subject certification and were trained in study procedures and design. All instruments and procedures for this study were reviewed and approved by the institution's Human Research Protection Program.

Field observations (see appendix A) were documented using hour-long visual traffic sweep techniques at a mix of low, medium, and high occupancy times. ${ }^{42}$ Research assistants received training in how to perform unobtrusive observations, which strives to avoid disrupting the observed environment. ${ }^{43}$ Using a paper-based template showing furnishing layouts, observers documented locations of individuals or groups, and uses of white boards, laptops or tablets, headphones, and books. Size of collaborations, defined as students observed actively discussing or sharing screens or devices, were also tracked. Interrater reliability testing was used to ensure consistency of both data recording and transfer into a spreadsheet for later analysis. A total of 301 observation sweeps were completed, capturing temporal behavioral profiles of 23,890 individuals.

\begin{tabular}{|l|l|c|}
\hline \multicolumn{2}{|c|}{ Overview of Informal Learning Space Sites } \\
\hline Site & Description & $\begin{array}{l}\text { ILS Seating } \\
\text { Capacity* }\end{array}$ \\
\hline $\begin{array}{l}\text { Learning } \\
\text { Commons (LC) }\end{array}$ & $\begin{array}{l}\text { Single floor located on first floor of main library. Majority collaborative, } \\
\text { open spaces with group study rooms and quiet study section. }\end{array}$ & 323 \\
\hline $\begin{array}{l}\text { Library South } \\
\text { Building (LS) }\end{array}$ & $\begin{array}{l}\text { Multistory, houses main library's collections. Majority quiet study } \\
\text { spaces for individuals and small groups. }\end{array}$ & 341 \\
\hline $\begin{array}{l}\text { College of } \\
\text { Business (CoB) }\end{array}$ & $\begin{array}{l}\text { Multistory, standalone building. Collaborative, open spaces with } \\
\text { group and private study rooms. }\end{array}$ & 441 \\
\hline $\begin{array}{l}\text { College of Nursing } \\
\text { (CoN) }\end{array}$ & $\begin{array}{l}\text { Multistory, standalone building, shares space with university health } \\
\text { services. Collaborative, open spaces with group study rooms. }\end{array}$ & 200 \\
\hline Union & $\begin{array}{l}\text { Multistory, standalone building; shares space with bookstore, } \\
\text { restaurants, other retailers. Collaborative, open spaces. }\end{array}$ & 367 \\
\hline *Note. ILS seating capacity includes only nonclassroom, commons spaces and does not reflect total \\
building seating capacity.
\end{tabular}

The survey instrument (see appendix B) was self-developed for this study according to Post-Occupancy Evaluation best practices ${ }^{44}$ and Bennett's conceptual model of student learning needs. ${ }^{45}$ It was primarily aimed at identifying the reasons or factors that could be attributed to overall satisfaction according to dimensions of successful learning environments: task completion, workspace, atmosphere, and needs fulfillment. ${ }^{46}$ Thus, several indices of items reflecting each dimension were created. The final instrument included 14 Likert-type scale items and two open-response items. The survey also gathered demographic data for gender, age, major, class standing, race/ethnicity, and international status.

The instrument was first piloted with six students and a panel of faculty and staff to confirm clarity, accuracy, and comprehension and establish content validity. Cross-sectional web survey data were gathered from students at each site $(\mathrm{N}=993)$, using random probability sampling. Research assistants provided tablets to students to complete the web-based survey immediately upon successful recruitment. 
Several analyses of observation and survey data were run using SPSS v. 25 to identify and quantify the factors relating to tasks and satisfaction. Frequency scores were analyzed to describe the sample and make statistical comparisons. Likert-type items were treated as interval for the purposes of analysis and interpretation, and one-way analysis of variance was calculated to identify potential differences among participants and across the five sites, where $p$-values less than 0.05 were considered as significant. Chi-square and Kruskal-Wallis nonparametric test for independent samples was used to measure the strength of association between categorical and ordinal variables (see appendix C). Not all participants answered all questions, and nonresponse items were coded as missing.

\section{Qualitative Data Collection and Analysis: Focus Groups}

Following preliminary quantitative analyses of observation and survey data, focus groups were conducted with a small, voluntary sample of survey participants from each of the five sites (n $=23$ of a possible 155 volunteers). Discussions followed a semistructured interview protocol, with five open-ended questions and a series of prompts aimed at enhancing and clarifying survey findings regarding their learning and space needs in the ILSs (see appendix D). Participants included 19 women and four men: 21 undergraduates and two graduate students, representing 18 different majors. Sessions were audiorecorded and transcribed verbatim by members of the research team. Focus group transcripts were analyzed thematically using the six-part process outlined by Braun and Clarke. ${ }^{47}$

\section{Findings}

\section{Occupancy}

Field observations were used to track occupancy and develop behavioral profiles within each of the five site locations (see table 2). Average occupancy across all sites was 23.8 percent, varying from 2.6 percent at the College of Nursing to 48.5 percent at the Learning Commons. The two library sites had the highest occupancies, both as a percentage of each site's total seating capacity and in number of persons. As cautioned by others, ${ }^{48}$ the use of actual occupancy instead of perceived explains some of the wide variance between the locations; tables in the

\begin{tabular}{|l|c|c|c|c|c|c|}
\hline \multicolumn{7}{|c|}{ TABLE 2 } \\
\hline $\begin{array}{l}\text { Site } \\
\text { (observations) }\end{array}$ & $\begin{array}{c}\text { LC } \\
(\mathbf{n = 5 9 )}\end{array}$ & $\begin{array}{c}\text { LS } \\
(\mathbf{n = 6 0 )}\end{array}$ & $\begin{array}{c}\text { CoB } \\
(\mathbf{n = 6 1 )}\end{array}$ & $\begin{array}{c}\text { CoN } \\
(\mathbf{n}=\mathbf{6 0})\end{array}$ & $\begin{array}{c}\text { Union } \\
(\mathbf{n}=\mathbf{6 1})\end{array}$ & $\begin{array}{c}\text { Total } \\
\text { (N= 301) }\end{array}$ \\
\hline Seating capacity & 323 & 341 & 441 & 200 & 367 & 1,672 \\
\hline Avg occupancy & $156.8(48.5)$ & $100.8(29.6)$ & $65.7(14.9)$ & $5.3(2.6)$ & $70.0(19.1)$ & $398.6(23.8)$ \\
\hline 1 person & $7,036(76.1)$ & $5,202(86.0)$ & $2,198(54.8)$ & $139(43.9)$ & $2,627(61.6)$ & $17,202(72.0)$ \\
\hline 2 group & $1,308(14.1)$ & $690(11.4)$ & $982(24.5)$ & $82(25.9)$ & $976(22.9)$ & $4,038(16.9)$ \\
\hline 3 group & $513(5.6)$ & $123(2.0)$ & $492(12.3)$ & $66(20.8)$ & $339(7.9)$ & $1,533(6.4)$ \\
\hline 4 + group & $392(4.2)$ & $34(0.6)$ & $336(8.4)$ & $30(9.5)$ & $325(7.6)$ & $1,117(4.7)$ \\
\hline Headphone use & $*$ & $2,387(39.5)$ & $493(12.3)$ & $9(2.8)$ & $823(19.3)$ & $3,712(25.4)$ \\
\hline Books on table & $*$ & $3,199(52.9)$ & $332(8.3)$ & $22(6.9)$ & $979(22.9)$ & $4,532(31.0)$ \\
\hline Total individuals & 9,249 & 6,049 & 4,008 & 317 & 4,267 & 23,890 \\
\hline *Data not gathered from this site. & & & & \\
\hline
\end{tabular}


library spaces on average seat fewer students than at the other sites, and students in the focus groups expressed a reluctance to share a table with strangers. For example, when thinking about the underuse of tables seating eight at the College of Business, one student observed: "They're never full, but you never really want to go to one that already has a person at it," and another added, "I personally wouldn't go and just sit at some random person's desk or table, that would just make me feel uncomfortable and I'd feel like I'm invading their space. So I probably wouldn't join someone, I probably would just go somewhere else."

\section{Profile of Users}

Survey data revealed broad portraits of the students at each of the ILSs, contextualizing the relationship of these users within the larger university population. Across the entire survey sample, a majority of students were white $(78.9 \%)$, female $(68.7 \%)$, domestic $(89.5 \%)$, undergraduates $(95.7 \%)$, between the ages of 19 and $22(93.7 \%)$. Students were frequent visitors to the respective locations, with more than half of respondents reporting more than 2 to 3 visits each week (see figure 1). Students in LS and CoB had significantly higher frequencies of visits when compared to the other two sites.

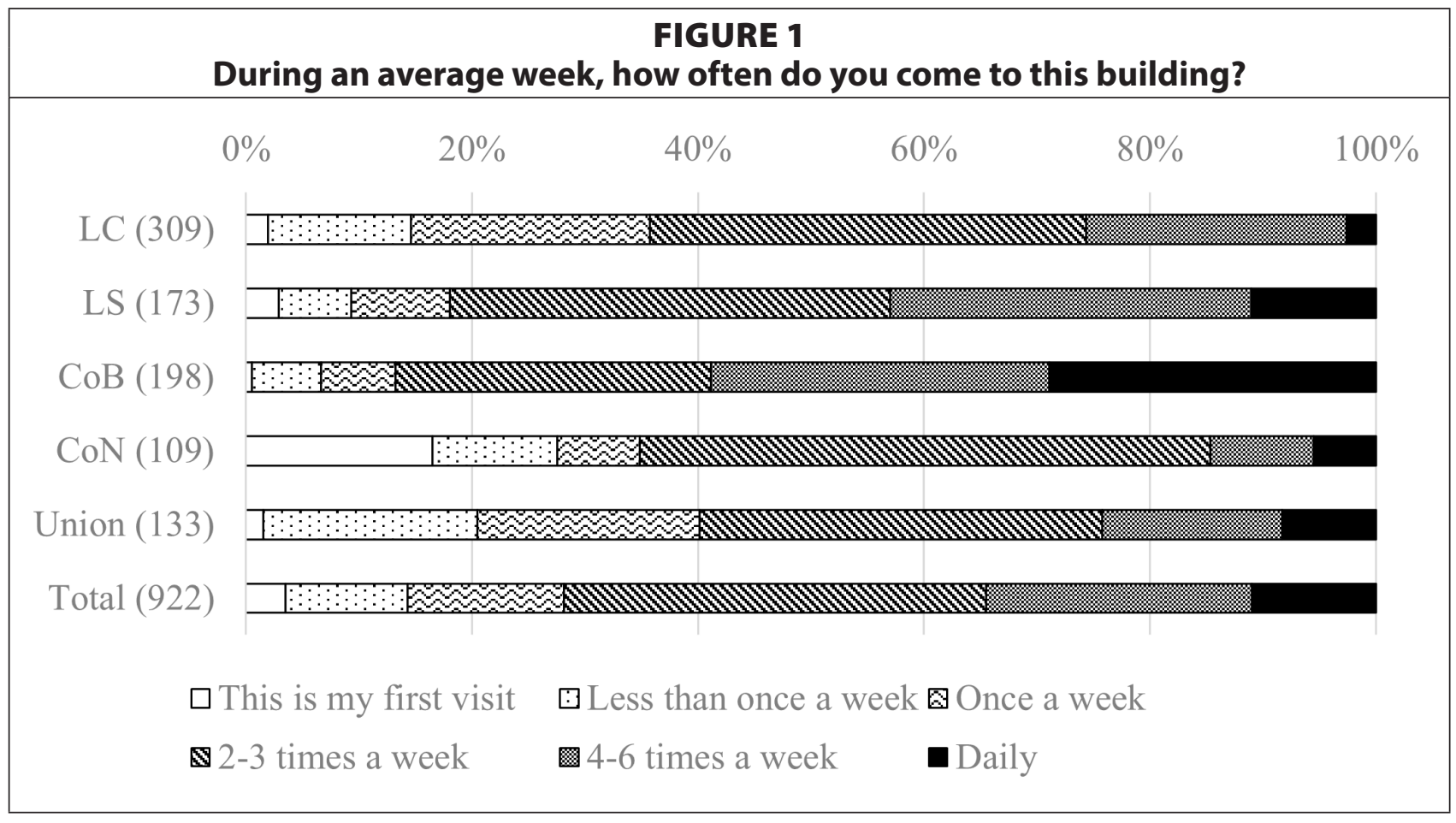

As shown in figure 2, graduate students, who account for 17.1 percent of the university population, were underrepresented in the spaces, representing only 3.7 percent of the total sample. ${ }^{49}$ In addition, except for the learning commons, freshmen were underrepresented, though this can be attributed to a small number of participants being excluded from the study due to 19 being the state's legal age of consent. Minor variance was also detected in terms of college affiliation, which was expected due to those colleges being located at a different campus, and gender. This gender disparity was also captured in observation data, showing more women $(53.3 \%)$ than men $(46.7 \%)$ using the spaces overall, which was unexpected as there are slightly more males (50.9\%) enrolled at the university than females $(49.1 \%)$. 


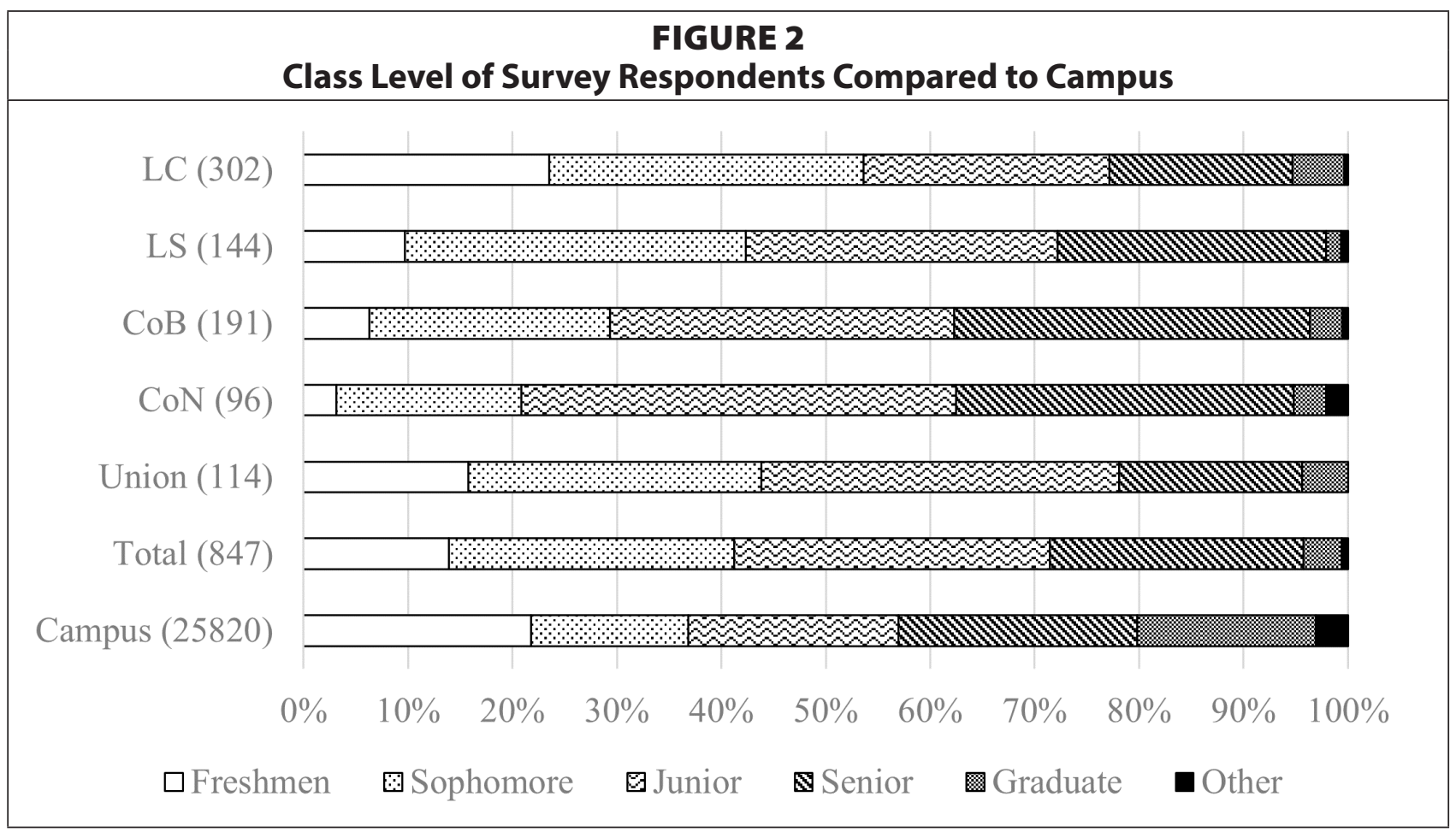

Most students surveyed in the $\mathrm{CoB}(72.3 \%)$ were indeed College of Business students, spurring a predictable conclusion that business majors are the primary users of this disciplinary-oriented space. However, business students, who comprise 17.0 percent of university enrollment and 30.5 percent of students surveyed, were hardly confined to this one site. Business majors represented 24.2 percent of students surveyed at the LC, 13.2 percent at the union, 13.9 percent at the LS, and 4.0 percent at the CoN. Conversely, at the $\mathrm{CoN}$, nursing majors comprised 57.6 percent of all students surveyed at that site, and 85.1 percent of total nursing majors in the survey sample. That only a small majority of students surveyed at the $\mathrm{CoN}$ were from this college was likely due to its co-location with the university health center. Observation data (see table 2) revealed low average occupancy for ILSs within both $\mathrm{CoB}(14.9 \%)$ and $\mathrm{CoN}(2.6 \%)$, suggesting that use of other spaces by these buildings' intended student populations should not be attributed to capacity issues.

Focus group conversations about this disparate representation regarding business and nursing students revealed a widening gap of privilege favoring these particular students. All business and nursing students frequented ILSs outside of their college, but expressed appreciation for keycard access to their buildings after hours. They attributed this restricted access to an increased sense of safety when compared to other locations, with one CoB student stating, "I feel like there should be something at the library to scan to get in every time because there's so many random people all the time. Just, like, old people all the time, just randoms, and you're like, 'How'd they get in here?'”

Just as majors at both colleges expressed frustration over nonmajors using the spaces, nonmajors perceived the colleges as off-limits. Multiple students remarked that they would not feel comfortable studying at the disciplinary colleges, fearing that they would be discovered and asked to leave. The one nonmajor in the $\mathrm{CoB}$ focus group acknowledged, "Sometimes I do feel kind of weird coming here," even when accompanied by business majors. The exclusivity of the disciplinary ILSs led students in the focus groups to contrast that with their perceptions of the common good locations. Students in the union, LC, and LS all remarked 
on the locations' inclusivity, using adjectives such as "neutral," "accepting," "welcoming," and "for everyone."

\section{Tasks, Needs, and Priorities}

Regarding their current visit, survey respondents varied widely in terms of tasks, needs, and priorities. Most students (78.0\%) anticipated staying at least one to two hours (see figure 3), though students in LS anticipated longer visits on average, with 41.6 percent selecting 3 or more hours.

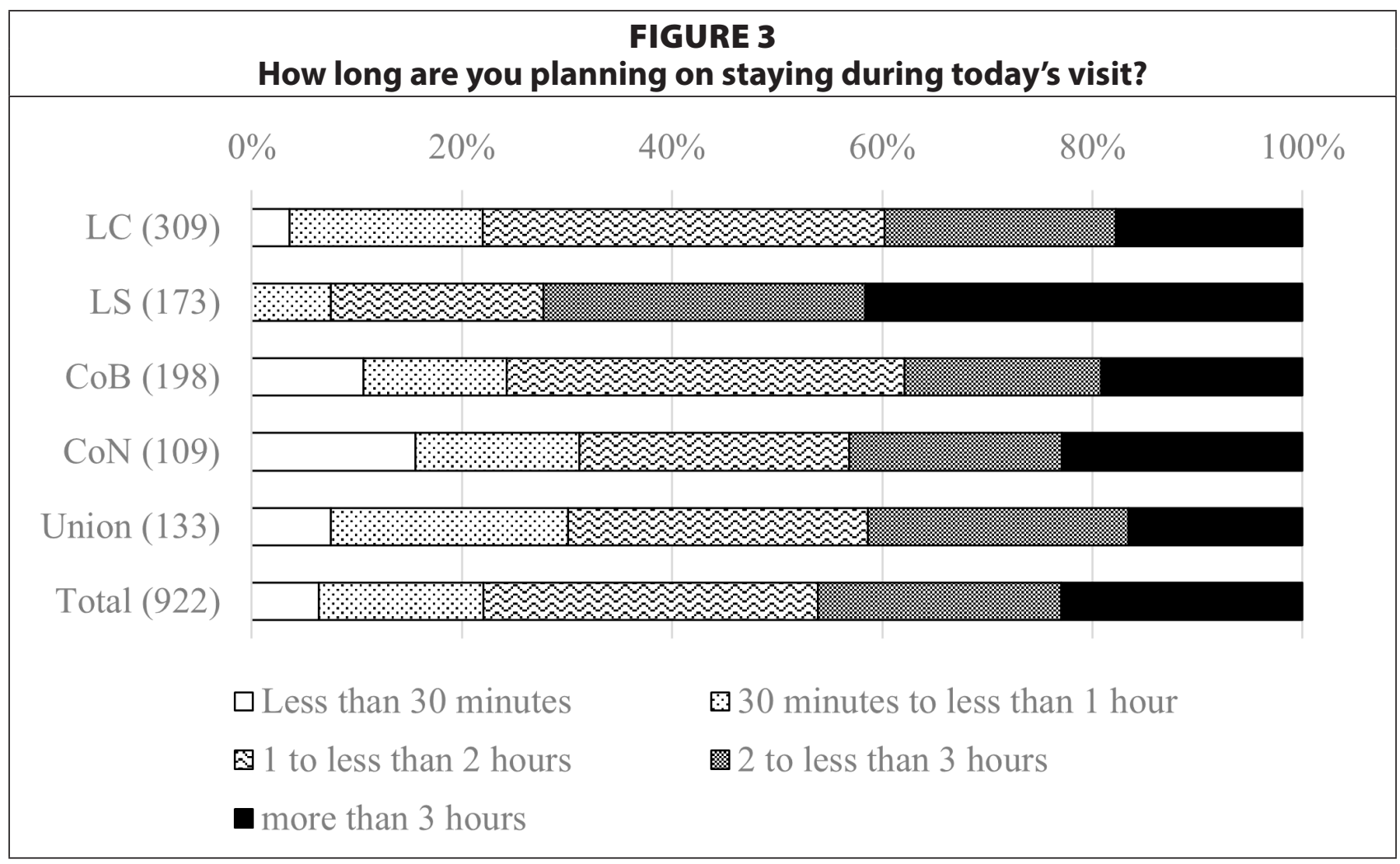

Academic coursework was the main task for students across all the sites (79.6\%). Despite four of five sites being largely oriented toward collaborative work, independent work was the main activity for half of students $(50.0 \%)$, followed by group coursework $(21.7 \%)$, with a small number (7.9\%) planning to do both during that day's visit (see figure 4). The highest percentage of students conducting independent coursework was located in LS (77.1\%).

This independent work was also apparent from observation data (see table 2), where 71.4 percent of all users were observed working alone. The majority of users in the library spaces $(80.0 \%)$ were recorded working independently, with more students at the LS $(86.0 \%)$ observed working alone than at the LC (76.1\%). Students at CoN exhibited more collaborative activity, with 56.1 percent of those observed working in groups of two or more. However, as this location had very low occupancy overall, the observation data are less reliable than the other locations.

When asked to identify the importance of fulfillment of various needs for completing their tasks (see table 3 in appendix C), students at all sites ranked Accomplishment (ability to fully complete task) as the most important $(\mathrm{M}=1.7, \mathrm{SD}=1.0)$. When compared with the other 


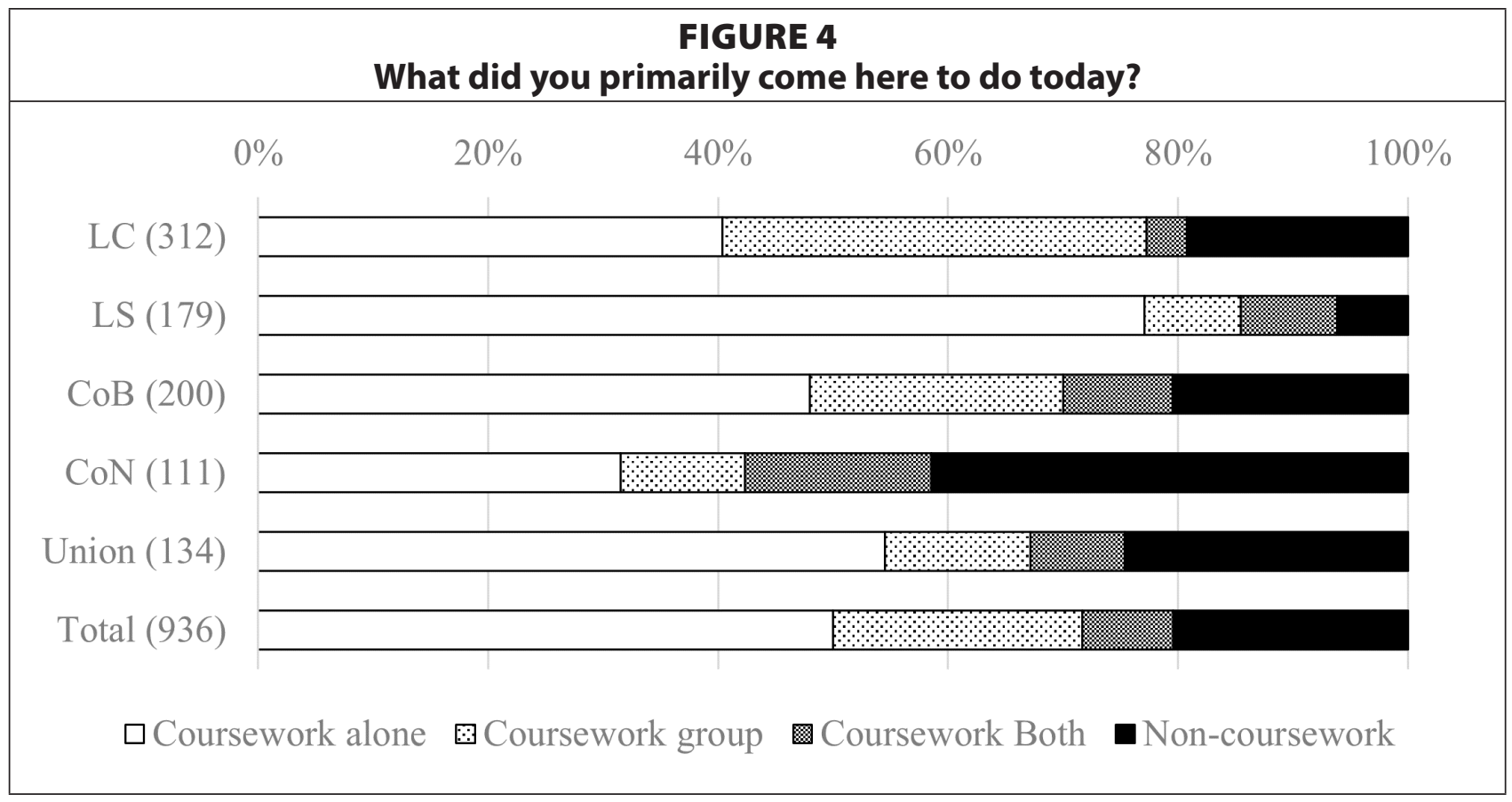

locations, students at LS regarded Autonomy (freedom from visual and/or noise distractions) as significantly more important $(\mathrm{M}=2.35, \mathrm{SD}=1.17$ ), and Belonging (feeling welcome; being part of a social community of peers) as significantly less important $(\mathrm{M}=4.27, \mathrm{SD}=.88)$. Students in the LS focus group agreed that belonging was likely less important to students in that space given their need to focus, with one stating, "[When] I want to study I really want to focus so I'm not really on the social connection side because we have a lot of opportunities to get social."

At all sites except for the LC, students were asked the open-ended question Of all the places on or off campus you can go to accomplish today's task, why did you choose to come here? (Briefly). Figure 5 displays the top terms used by 571 students responding to this prompt. A variety of reasons were provided, with very few commonalities across the sites. The top term Class (example: "I have a lot of classes in this building") was referenced by more than one third of respondents $(34.3 \%)$, a majority $(80.7 \%)$ of whom were located at either the CoB or CoN. Of 35 respondents using terms relating to Food, 88.6 percent came from students located at the union. The term Library was used by 35 students, 71.4 percent of whom were located there. The 10 students using that term from other locations used it as a framing device in ways that acknowledged the library's central identity as a place to conduct academic work: the library was either too busy to find a seat or too quiet for their needs. Quiet was used by 117 (24.9\%) students, 64.1 percent of whom were located at LS. Nearly half (47.8\%) of LS respondents mentioned Quiet. Study and Distractions were also frequently used by respondents at that location (24.8\% and $21.7 \%$, respectively).

This synonymizing of quiet and library was acknowledged by the students in the focus group. "I think it's just an accepted notion in our society that library equals quiet, that I can come here and be productive," "I need silence, which is why I come to the library a lot," "When I think Library, I think the big red roof here was always just iconic, that's [the] Library, that's [the university's] major library and that's where I study if I need to get things done. It was a preconceived notion in my head that library, big red thing, study... It's just kinda known... [the] library is a good place to study." This association of the library as a place to study was 


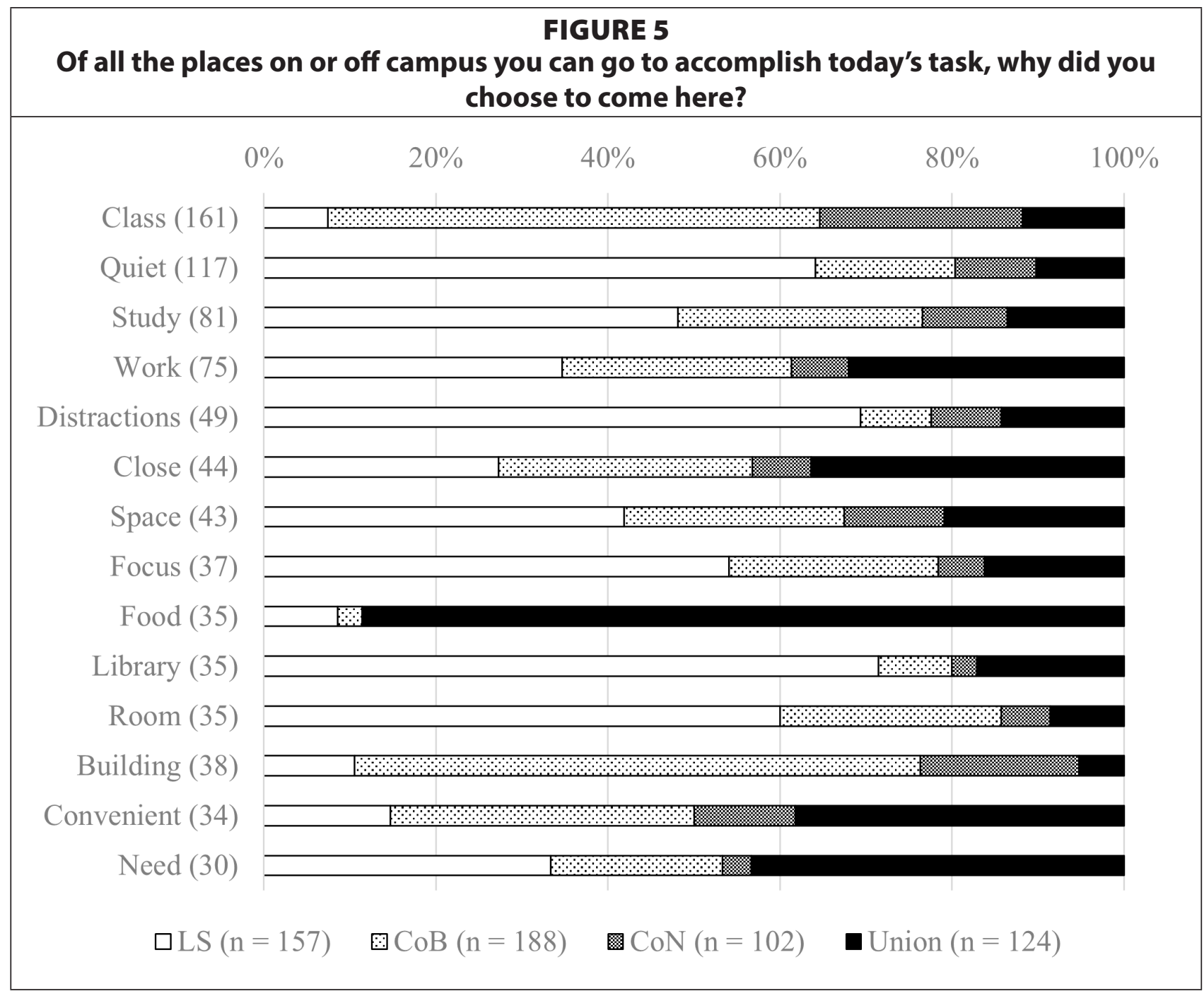

often established early in their academic careers, "I think when they take you on your tour, I remember coming to [the] library. And we walked through and they said, "This is the Learning Commons,' and you just get engulfed in it right away. So I think that's kind of the go-to." "I know where everything is here, it is very familiar. We learned about it our freshman year."

There was little consensus among students regarding the importance of various workspace and ambience needs to their productivity. Access to wireless $(\mathrm{M}=1.72, \mathrm{SD}=1.02)$ and power outlets $(\mathrm{M}=1.99, \mathrm{SD}=.96)$ stood out as essential for almost all students at all locations, but other features exhibited wide variance in ratings. There were no statistically significant differences between features such as Noise privacy $(\mathrm{M}=3.08, \mathrm{SD}=2.1)$ and Visual privacy $(\mathrm{M}=3.93$, $\mathrm{SD}=2.26)$; however, pairwise comparisons with adjusted $p$ values did reveal that students in the LS ranked a need for Individual study tables, $\chi^{2}(3)=22.1, p<.001$, and Quiet atmosphere, $\chi^{2}(4)$ $=22.82, p<.001$, significantly higher than the other locations. Surprisingly, average student rankings $(\mathrm{M}=3.5, \mathrm{SD}=2.6)$ for Being around others studying placed it quite low when compared to the other ambience features, though the wide deviation suggests a lack of agreement on this issue. This disagreement was reflected in the focus groups, with some students agreeing with the statement, "I think [being around others studying] is extremely important...For me, it's really mental. Even if I'm not working with someone I can be like, 'Yeah, these people are also college students working hard,' and it just motivates me." However, other students 
found the presence of others distracting: "For me, that's not really helpful. I try to get away from people as much as possible when I'm studying, at least by myself."

In focus group conversations, students at all sites acknowledged a desire for more quiet spaces across the campus. Nursing students in particular felt the campus's ILSs-including those within their own college-did not provide enough quiet spaces to support the deep level of concentration required to master their material. All six students acknowledged that the library would be the best environment for this level of focus but stated that the high volume of users presented an insurmountable distraction in itself: "I feel like I have to compete for a space. And if I find a nice open space, there's usually people talking, or unless you get a private room, which you have to reserve, then someone's always knocking on the hour and they're like, 'He reserved this,' and then you have to move. So I need to sit in one spot and just hammer it out for like three or four or five hours. That's how I study, in concentrated doses." With nowhere else to go, these students resorted to studying at home, which they agreed was an undesirable option due to the many distractions associated with roommates, chores, and leisure.

Notably absent from students' needs for productivity was the library's physical collections. Observation data (see table 2) revealed that a far greater percentage of students (52.9\%) in LS had books on their table when compared with the other locations, but students indicated that these were most likely personal materials, such as textbooks. Students in the focus groups all carried books with them, with one student describing the extensive contents of her backpack as "Phone, my iPad, my computer, 3,000 books, huge notebook, other papers, things for whatever I'm working on, water bottle, coffee." Of 140 respondents, only 35 students identified the Library's collections (books) as being at all important for that day's productivity. None of the students in the LS focus group had ever checked out any library resources. They agreed that the books were important symbols of scholarly work, "It makes it feel like you're in a library," that provided desirable privacy protections and helped to limit distractions: "The books kind of are like a little blockade though. And then if all the books were gone then it's just a big open room."

\section{Satisfaction}

On average, students expressed high satisfaction regarding all workspace and ambience aspects of the locations. Out of a maximum of 5 , the sites received an average rating of $4.4(\mathrm{SD}=$ .62). Small variance was detected between the sites, with students in LS reporting significantly higher satisfaction levels with regard to Overall noise $(\mathrm{M}=4.22, \mathrm{SD}=.90)$ and Size of personal workspace $(\mathrm{M}=4.49, \mathrm{SD}=.75)$. Students in $\mathrm{LS}$ reported less satisfaction $(\mathrm{M}=4.03, \mathrm{SD}=1.01)$ with Overall aesthetics than the other locations, significantly so, $\chi^{2}(3)=21.31, p<.001$, when compared with the brand-new environments of the $\mathrm{CoB}(\mathrm{M}=4.43, \mathrm{SD}=.76)$ and the $\mathrm{CoN}(\mathrm{M}$ $=4.46, \mathrm{SD}=.79)$. Unlike the other locations, the library's stacks have not been appreciably updated or renovated since the 1970s, as evidenced by the expanse of utilitarian, metal desks.

While the aesthetics of LS are unremarkable, the stacks areas are unique due to having private study carrels with relatively large tables, separated by metal dividers. Conversely, there are very few tables designated for independent work in the other locations. Students in the focus groups expressed a preference for the updated aesthetics of the newer spaces, agreeing with one student's comment that, "It's more fun to have the variety and the different spaces and the style versus just desks with chairs." However, when the need to pursue 
serious study arose, the need for a quiet atmosphere outweighed contemporary style. As one student explained, "If I' $\mathrm{m}$ in the mood to be super productive, then I would go to the quiet room, whereas if I was in the mood where I was like, 'I don't really feel like doing something, but I'm just going to get my busywork done really quick,' then I would go to [the library's busier spaces with more comfortable furniture]. I feel like there's a big difference between doing actual homework, like completing a task, compared to just studying, like opening up a book and just studying."

The students largely agreed that the sites provided adequate support for their psychological and well-being needs. The sites received an average rating of 4.2 out of 5 ( $\mathrm{M}=4.2, \mathrm{SD}$ $=.78$ ) regarding how well they supported students' ability to complete their tasks. Again, the LS revealed statistically significant differences from the other locations, with students providing significantly lower ratings regarding This space helps me connect with my peers (M $=3.8, \mathrm{SD}=1.05)$, and significantly higher ratings for This space helps me focus on my task $(\mathrm{M}=$ $4.6, \mathrm{SD}=.60$ ). The differences detected for these particular measures were in alignment with differences detected from students' earlier rankings of their importance; students in LS were both less interested in interacting with peers and more vested in engaging with their work.

\section{Discussion}

The recent increase in the number of ILSs is certainly a desirable benefit to the students at the university. The spaces are popular locations for students to conduct their academic work, and students appreciated having multiple locations to go to, with strong evidence that they frequently migrated throughout two or more locations with task and mood as primary drivers. Students acknowledged the inherent benefits of studying on campus including safety, proximity, and communal study environments, and although not identified as critical to their needs, they valued the contemporary and comfortable aesthetics of the newer spaces.

The ILS pendulum has swung too far in the direction of collaborative learning spaces, where the success of the space is measured in decibels. The academic library has long been established as a place where students conduct academic work; $; 0$ however, independent academic work was the main goal for students across all five of the ILSs in this study. The relative absence of graduate students throughout all of the spaces, and nursing students from their own building, suggests that the campus's ILS ecosystem is failing to support students carrying out the most intensive academic work, and this should be cause for concern. More protections such as ensuring visual and acoustic privacy, replacing the larger group tables with smaller furnishings that could be easily reconfigured, and deploying movable whiteboards throughout the spaces would help students assume greater control over their spaces while still maintaining flexibility when required.

The introduction of the full-service colleges manifests additional complications within the ILS ecosystem. Both the College of Business and the College of Nursing were constructed with the intent that students would be able to come to the building in the morning and fulfill all of their daily academic, personal, and productivity needs in a self-contained environment. Yet the students in these disciplines continue to frequent other ILSs across campus. The existence of these spaces is certainly a boon for students in the respective colleges, who express feelings of ownership over these spaces while still availing themselves of the plethora of choices of campus study spaces. It does, however, raise the question of what does it mean for students in other disciplines who feel apprehensive about using "someone else's" space? When explor- 
ing the creation of discipline-specific ILSs, colleges should not assume that their students will choose these spaces over the library or other common good ILSs. Additionally, as building space becomes an increasingly precious commodity on college campuses, administrators should consider carefully how much space should be dedicated to ILSs that are perceived by students to be exclusive, thereby minimizing their utility.

In the ILS ecosystem, the library functions as the fulcrum for study. There are signs that students migrate among spaces - to where their mood and tasks take them-and it is the quiet spaces within the library that serve as their baseline for the level of studiousness needed. Even as students use and value sociocollaborative spaces, "the Library" plays a central role in their perception of informal learning. As May and Swabey's study of five different libraries found remarkable similarities in students' use, this study found a near universal conception of library as a space for intensive study. ${ }^{51}$

Finally, the neglect of the traditional, quiet library spaces ultimately signals their devaluing, which is felt by the entire campus. Rather than reserving funding for improvements unless a space is transformed into a collaborative study area, these spaces in which the most intensive independent work is undertaken should be afforded the same respect. In this study, students in the quieter spaces were deliberate in their choice of location, exhibiting the selfregulatory processes of self-initiation and self-monitoring attributed to successful informal learning. ${ }^{52}$ This voluntary selection of place exhibits a positive metacognitive awareness in which students recognize the relationship between their learning environment and their ability to learn. The institutional barriers of neglect did not deter students from the spaces; even when the stacks areas were filled with book trucks, students were doggedly present (see figure 6). The affability of students, however, should not be taken for granted, and, at some point, the library's most ardent users will go where their needs are more comfortably supported.

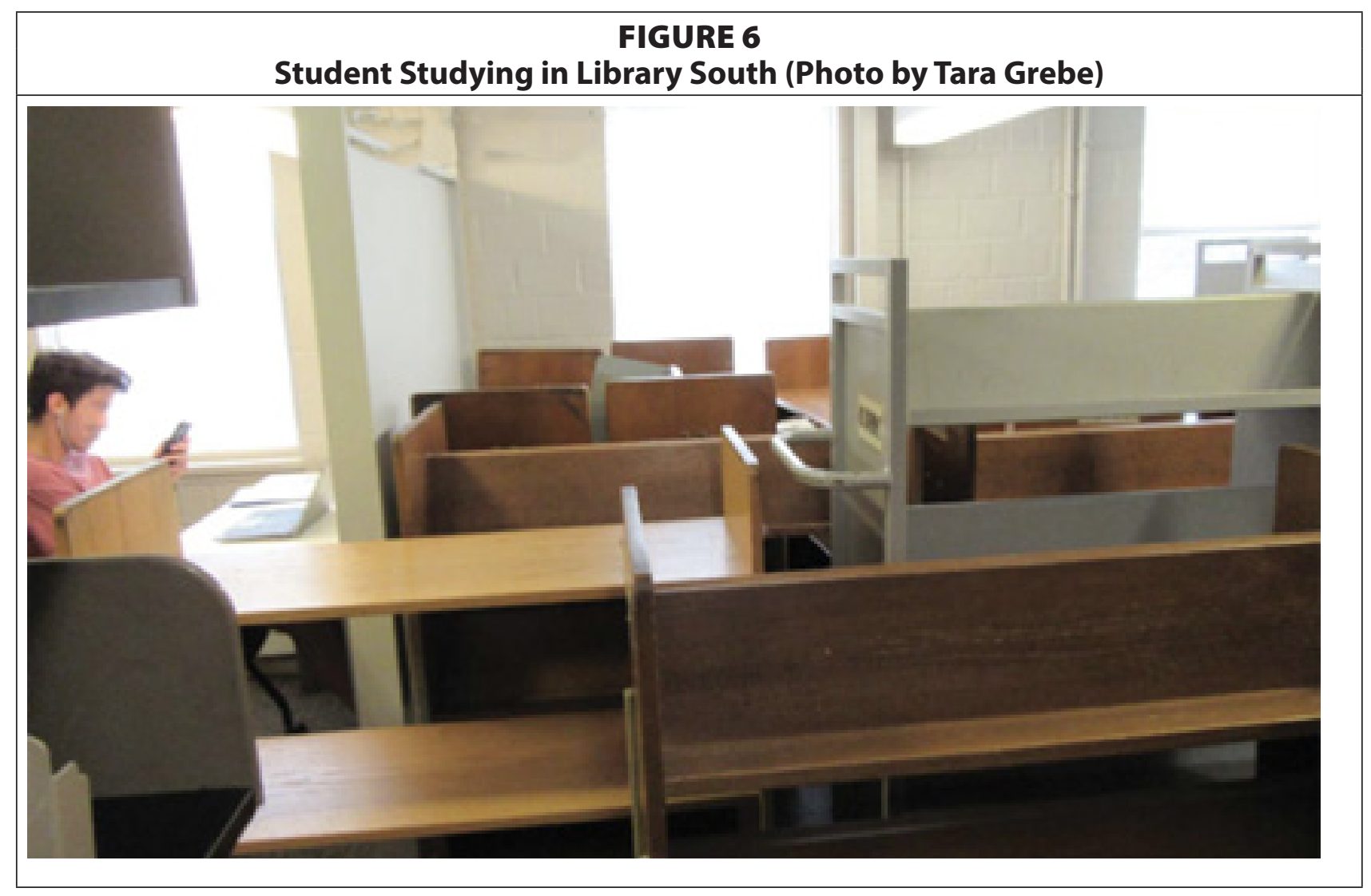




\section{Limitations and Unresolved Issues}

This study was impacted by certain limitations, and numerous future research questions remain. First, findings based on observations and survey responses relied on cross-sectional data, and future longitudinal models of research are needed to examine how students' uses and needs within ILSs develop over time. Second, the study relied upon data gathered exclusively from students actively inhabiting each of the five informal learning sites. These students' evaluations of a space they voluntarily selected to reside within likely resulted in a positive skew for various assessment metrics. Gathering data from a broader population of students and including those who do not necessarily use these spaces or find them supportive of their study needs would help resolve at least some of the problems of exclusion as outlined by Berman, ${ }^{53}$ while creating a more generalizable dataset. Third, the explanatory, correlational nature of the study limits the ability to recognize causal effects. By using an experimental framework, future research could help identify causal effects of students' use of various ILSs and academic success. Finally, this study does not include perceptions of the faculty. A fundamental purpose of a campus is to bring together students and faculty for learning, ${ }^{54}$ thus, an attempt needs to be made to identify where, in addition to the classroom, these interactions occur.

\section{Conclusion}

Informal learning spaces, despite the increased interest and prevalence beyond libraries, are not an abundant commodity. They have relatively small seating capacities, limited staff available for oversight, and, unless they are ostensibly, observably, and overtly occupied, face threat of being prescribed another use by universities facing myriad stressors. While simply filling a space with students is a tempting way to assert its value, this quick fix does little to support the learning needs of the campus community.

The perennial physical space issues faced by universities are increasingly compounded by the existential crises of a changing climate that demands more sustainable practices and a pandemic that has placed innumerable restrictions on their use. Where satisfying large swaths of the populace might once have been possible, administrators and librarians will now have to make challenging decisions regarding which needs and behaviors to prioritize.

Understanding core contributions of academic library spaces is more important than establishing its users' satisfaction; within higher education learning organizations, a task hierarchy is explicit, and fostering environments in which students can best engage with their coursework should be perceived as the main priority. Committing to supporting the learning needs of the academic community and then assessing students' satisfaction in that context is what validates these measures. Conducting in-depth explorations into campus ILSs, such as this, reveals strengths and weaknesses of the spaces per the individuals who inhabit them. By observing and surveying users, the holistic functioning of this system is illuminated in ways that would otherwise be missed. These data can equip libraries with evidence underscoring their unique value. Time and time again, space use studies like this have revealed the singular importance of the physical library as a place for quiet, reflective study. In addition to creating sociocollaborative spaces, libraries have a responsibility to invest in spaces supportive of independent learners; instead of disregarding these spaces as though they are an outdated relic of the past, libraries should acknowledge them as a defining value within the institution. 


\section{Acknowledgments}

This study was funded by a grant from the Maude Hammond Fling Faculty Research Fellowship through the University of Nebraska-Lincoln's Research Council. The authors would like to thank the University Libraries, Nebraska Union, College of Business, and College of Nursing for welcoming us into their spaces, and the Undergraduate Creative Activities and Research Experience program for their support. The authors are indebted to the exceptional work and tenacious spirit of undergraduate student research assistants Ashlynn Engelhard, Annie Mimick, Mikinna McGerr, Tara Grebe, Tiffany Schweer, and Savannah Scoville. 
APPENDIX A

Behavior Map and Key for One Complete Observation Sweep on Second Floor of Library South
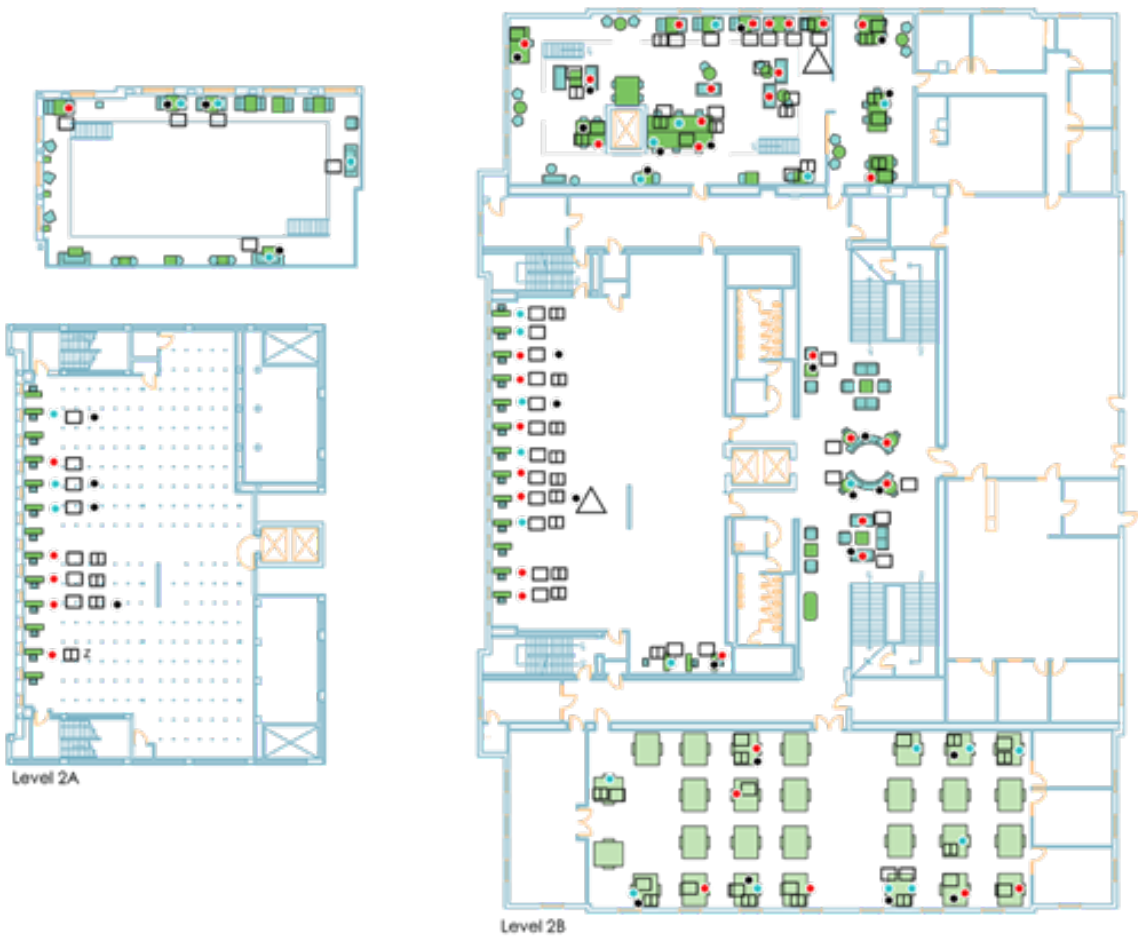

Floor 2

Key
- femule i male $\bigcirc$ collaboeation $\square$ dectronic use
not induding cell phones

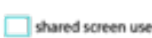

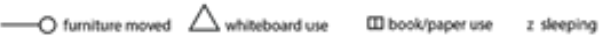




\section{APPENDIX B}

\section{Survey Instrument}

1. What did you primarily come here to do today? (click ALL that apply)

$\square \quad$ I'm working on coursework alone

$\square \quad$ I'm working on coursework with a group

$\square \quad$ I'm working on noncoursework-related activities alone

$\square \quad$ I'm working on noncoursework-related activities with a group

$\square \quad$ I'm mostly socializing

$\square \quad$ I'm mostly relaxing

$\square$ Something else:

2. How long are you planning on staying during today's visit?

$\square \quad$ Less than 30 minutes

$\square \quad 30$ minutes to less than 1 hour

1 to less than 2 hours

$\square \quad 2$ to less than 3 hours

$\square \quad 3$ hours or more

3. During an average week, how often do you come to this building?

$\square \quad$ This is my first visit

$\square \quad$ Less than once a week

$\square$ Once a week

2-3 times a week

口 4-6 times a week

$\square \quad$ Daily

4. Rank the following needs in order of their importance for completing today's task in your current location (1 most important to 5 least important):

$\square \quad$ Accomplishment (ability to fully complete task)

$\square \quad$ Autonomy (freedom from visual and/or noise distractions)

$\square$ Belonging (feeling welcome; being part of a social community of peers)

$\square$ Engagement (ability to engage deeply with task)

$\square \quad$ Safety (freedom from harassment or unwanted attention)

5. Of all the places on or off campus you can go to accomplish today's task, why did you choose to come here? (Briefly)

6. Thinking about the space you are currently in, how satisfied are you regarding the layout of each of the following (1 extremely dissatisfied to 5 extremely satisfied):

$\square \quad$ Size of my personal workspace

$\square$ How well the layout supports my task for today

$\square$ Amount of space for my personal belongings

$\square \quad$ Ability to adjust the layout to meet my needs

7. Thinking about the space you are currently in, how satisfied are you regarding the following features of the interiors ( 1 extremely dissatisfied to 5 extremely satisfied):

$\square$ Wall colors

$\square \quad$ Flooring materials

$\square$ Workspace surface finishes (such as desktop, table)

$\square \quad$ Aesthetics (views, visuals, and other aspects)

8. Thinking about the space you are currently in, how satisfied are you regarding each aspect 
of your surrounding environment (1 extremely dissatisfied to 5 extremely satisfied):

$\square$ Temperature

$\square \quad$ Ability to control temperature to meet my needs

- Air quality (like stuffy/stale air, cleanliness, odors)

$\square \quad$ Artificial lighting

$\square \quad$ Ability to control lighting to meet my needs

$\square$ Views to the outside/windows

$\square$ Overall cleanliness

9. Thinking about the space you are currently in, how satisfied are you regarding each aspect of noise and privacy ( 1 extremely dissatisfied to 5 extremely satisfied):

- Sound privacy (for example, ability to hold private conversations)

- Visual privacy (for instance: I am not overly visible to others; no looking over my shoulder or sneaking up)

- Overall level of noise in the area

10. Please rank the following workspace features in order of importance to your productivity today (1 is most important; do not rank unimportant items)

Ability to adjust workspace

$\square$ Comfort of furniture

- Individual study table

- Sufficient space to do work

Uncluttered workspace

$\square \quad$ Workspace colors and textures

11. Please rank the following ambience features in order of importance to your productivity today (1 is most important; do not rank unimportant items)

$\square$ Being around others who are studying

$\square$ Fresh air

- Noise privacy (for example: my conversations or actions are not easily overheard)

口 Odorless environment

- Quiet atmosphere

$\square \quad$ Thermal comfort

Visual comfort

12. Please rank the following services and amenities in order of importance to your productivity today (1 is most important; do not rank unimportant items)

- Availability of food and drinks

$\square$ Access to outlets/power

$\square$ Site provided computers or technology

Library collections (books)

$\square$ Whiteboards

․ Wireless connectivity (WiFi)

13. Rate your level of agreement with each of the following statements (1 extremely dissatisfied to 5 extremely satisfied):

․ I feel safe in this space

- I feel connected to my peers in this space

$\square \quad$ This space helps me achieve my goals

$\square \quad$ This space helps me focus on my task 
$\square \quad$ I feel as though I am welcome in this space

14. How well does your choice of space support your ability to get your job done today?

$\square \quad$ Not well at all

口 Slightly well

口 Moderately well

Very well

$\square$ Extremely well

15. Overall, how satisfied are you with this space?

Extremely dissatisfied

- Somewhat dissatisfied

- Neither satisfied nor dissatisfied

$\square$ Somewhat satisfied

$\square \quad$ Extremely satisfied

16. Do you have any comments, suggestions, or feedback you would like to share with us about this space or the building in general?

\section{Demographic portion}

1. I identify my gender as:

$\square$ Female

口 Male

$\square$ Another gender identity:

I prefer not to answer

2. What age are you today?

19-20

21-22

23-24

25-29

30-34

35-39

- 40 and older

3. What is your class level?

First year or freshman

$\square$ Sophomore

$\square$ Junior

$\square$ Senior

- Graduate

$\square \quad$ Other

4. Within what college/school is your current major/program of study? (click ALL that apply)

$\square$ Agricultural Sciences \& Natural Resources

Architecture

$\square$ Arts \& Sciences

Business

$\square$ Education \& Human Sciences

$\square$ Engineering

Exploratory \& Pre-Professional Advising Center (Undeclared) 
$\square \quad$ Fine \& Performing Arts

$\square$ Journalism \& Mass Communications

$\square \quad$ Nursing

$\square \quad$ Public Affairs \& Community Services

$\square \quad$ I'm not sure

$\square$ Other

5. What is your racial or ethnic identification? (click ALL that apply)

$\square$ American Indian or Alaska Native

$\square$ Asian or Asian American

$\square$ Black or African American

$\square$ Caucasian or White

$\square \quad$ Hispanic or Latino

$\square$ Native Hawaiian or Other Pacific Islander

$\square$ Another identity:

$\square \quad$ I prefer not to answer

6. Are you an international student?

$\square$ Yes

$\square \quad$ No 


\section{APPENDIX C}

\begin{tabular}{|c|c|c|c|c|c|c|c|}
\hline \multicolumn{8}{|c|}{$\begin{array}{c}\text { TABLE } 3 \\
\text { Needs Fulfillment for Task Completion }\end{array}$} \\
\hline \multirow{6}{*}{$\begin{array}{l}\text { Site } \\
\text { Accomplishment }\end{array}$} & \multirow{2}{*}{\begin{tabular}{|l|} 
Site \\
CoB \\
\end{tabular}} & \multirow{2}{*}{\begin{tabular}{c|c} 
\\
145
\end{tabular}} & \multirow{2}{*}{\begin{tabular}{c|}
$M$ \\
1.67
\end{tabular}} & \multirow{2}{*}{$\begin{array}{c}\text { SD } \\
1\end{array}$} & \multirow{2}{*}{$\begin{array}{c}\text { Mean Rank } \\
243.15\end{array}$} & \multicolumn{2}{|c|}{ Test Statistics } \\
\hline & & & & & & Chi-Square & 2.51 \\
\hline & $\mathrm{CoN}$ & 91 & 1.7 & 0.96 & 251.53 & Df & 3 \\
\hline & LS & 154 & 1.77 & 0.97 & 264.72 & Asymp. Sig. & 0.474 \\
\hline & Union & 120 & 1.8 & 1.1 & 263.66 & & \\
\hline & Total & 510 & 1.7 & 1 & & & \\
\hline \multirow[t]{5}{*}{ Autonomy } & $\mathrm{CoB}$ & 145 & 2.8 & 1.3 & 265.14 & Chi-Square & 24.47 \\
\hline & $\mathrm{CoN}$ & 91 & 2.9 & 1.3 & 270.42 & $D f$ & 3 \\
\hline & LS & 154 & 2.4 & 1.2 & 209.9 & Asymp. Sig. & $.000^{a}$ \\
\hline & Union & 120 & 3.1 & 1.4 & 291.06 & & \\
\hline & Total & 510 & 2.8 & 1.3 & & & \\
\hline \multirow[t]{5}{*}{ Belonging } & $\mathrm{CoB}$ & 145 & 3.7 & 1.2 & 239.53 & Chi-Square & 26.8 \\
\hline & $\mathrm{CoN}$ & 91 & 3.7 & 1.2 & 237.63 & $D f$ & 3 \\
\hline & LS & 154 & 4.3 & 0.88 & 304.54 & Asymp. Sig. & $.000^{\mathrm{a}}$ \\
\hline & Union & 120 & 3.5 & 1.4 & 227.13 & & \\
\hline & Total & 510 & 3.8 & 1.2 & & & \\
\hline \multirow[t]{5}{*}{ Engagement } & $\mathrm{CoB}$ & 145 & 2.9 & 1.2 & 250.96 & Chi-Square & 8.75 \\
\hline & $\mathrm{CoN}$ & 91 & 3.2 & 1.3 & 290.36 & Df & 3 \\
\hline & LS & 154 & 2.8 & 1 & 235.83 & Asymp. Sig. & $.033^{b}$ \\
\hline & Union & 120 & 3 & 1 & 262.1 & & \\
\hline & Total & 510 & 2.9 & 1.1 & & & \\
\hline \multirow[t]{5}{*}{ Safety } & $\mathrm{CoB}$ & 145 & 3.9 & 1.3 & 274.06 & Chi-Square & 6.83 \\
\hline & $\mathrm{CoN}$ & 91 & 3.5 & 1.5 & 229.78 & Df & 3 \\
\hline & LS & 154 & 3.8 & 1.2 & 262.73 & Asymp. Sig. & 0.078 \\
\hline & Union & 120 & 3.6 & 1.4 & 243.3 & & \\
\hline & Total & 510 & 3.7 & 1.3 & & & \\
\hline \multicolumn{8}{|c|}{$\begin{array}{l}\text { Note. Likert-type scale } 1 \text { most important to } 5 \text { least important. } \\
\text { a Pairwise differences detected between LS-all sites, } p<.05 \\
\text { b Pairwise differences detected between LS-CoN sites, } p=.038\end{array}$} \\
\hline \multicolumn{8}{|c|}{$\begin{array}{c}\text { TABLE } 4 \\
\text { Workspace and Ambience Needs for Productivity }\end{array}$} \\
\hline Function & Site & $N$ & $M$ & SD & Mean Rank & Test Statistic & \\
\hline \multirow[t]{6}{*}{ Individual study table } & LC & - & - & - & - & Chi-Square & 22.1 \\
\hline & $\mathrm{CoB}$ & 138 & 2.38 & 1.36 & 221.82 & $D f$ & 3 \\
\hline & $\mathrm{CoN}$ & 67 & 2.55 & 1.56 & 228.56 & Asymp. Sig. & $.000^{\mathrm{a}}$ \\
\hline & LS & 125 & 1.78 & 1.11 & 168.4 & & \\
\hline & Union & 86 & 2.57 & 1.55 & 229.79 & & \\
\hline & Total & 416 & 2.27 & 1.4 & & & \\
\hline
\end{tabular}




\begin{tabular}{|c|c|c|c|c|c|c|c|}
\hline \multirow[t]{6}{*}{ Others studying } & LC & - & - & - & - & Chi-Square & 10.28 \\
\hline & CoB & 109 & 3.34 & 2.64 & 136.23 & $D f$ & 3 \\
\hline & CoN & 37 & 4.51 & 2.48 & 180.03 & Asymp. Sig. & $.016^{b}$ \\
\hline & LS & 76 & 3.55 & 2.64 & 145.52 & & \\
\hline & Union & 63 & 3.11 & 2.44 & 129.92 & & \\
\hline & Total & 285 & 3.5 & 2.6 & & & \\
\hline \multirow[t]{6}{*}{ Noise privacy } & LC & - & - & - & - & Chi-Square & 1.72 \\
\hline & $\mathrm{CoB}$ & 120 & 3.09 & 2.24 & 170.85 & $D f$ & 3 \\
\hline & $\mathrm{CoN}$ & 66 & 3.05 & 2.14 & 169.96 & Asymp. Sig. & 0.633 \\
\hline & LS & 96 & 2.91 & 1.8 & 172.42 & & \\
\hline & Union & 66 & 3.36 & 2.2 & 188.7 & & \\
\hline & Total & 348 & 3.08 & 2.1 & & & \\
\hline \multirow[t]{6}{*}{ Quiet atmosphere } & LC & 151 & 2.04 & 0.83 & 257.59 & Chi-Square & 22.82 \\
\hline & $\mathrm{CoB}$ & 130 & 2.72 & 1.93 & 289.92 & $D f$ & 4 \\
\hline & $\mathrm{CoN}$ & 68 & 2.31 & 1.53 & 260.68 & Asymp. Sig. & $.000^{c}$ \\
\hline & LS & 122 & 1.93 & 1.37 & 217.21 & & \\
\hline & Union & 52 & 3.1 & 2.14 & 311.81 & & \\
\hline & Total & 523 & 2.33 & 1.57 & & & \\
\hline \multirow[t]{6}{*}{ Visual privacy } & LC & - & - & - & - & Chi-Square & 0.938 \\
\hline & $\mathrm{CoB}$ & 97 & 4.13 & 2.41 & 150.37 & $D f$ & 3 \\
\hline & $\mathrm{CoN}$ & 50 & 3.78 & 2 & 141.28 & Asymp. Sig. & 0.816 \\
\hline & LS & 86 & 3.72 & 2.01 & 139.41 & & \\
\hline & Union & 95 & 4.04 & 2.56 & & & \\
\hline & Total & 287 & 3.93 & 2.26 & & & \\
\hline \multirow[t]{6}{*}{ Onsite food } & LC & 138 & 2.03 & 0.83 & 161.33 & Chi-Square & 88.4 \\
\hline & $\mathrm{CoB}$ & 110 & 2.95 & 1.75 & 257 & $D f$ & 4 \\
\hline & $\mathrm{CoN}$ & 50 & 3.08 & 0.97 & 300.25 & Asymp. Sig. & .000 \\
\hline & LS & 97 & 3.39 & 1.51 & 306.29 & & \\
\hline & Union & 86 & 2.62 & 0.923 & 240.3 & & \\
\hline & Total & 481 & 2.73 & 1.36 & & & \\
\hline \multirow[t]{6}{*}{ Power outlets } & LC & 173 & 2.14 & 0.69 & 370.6 & & \\
\hline & $\mathrm{CoB}$ & 149 & 2.21 & 1.29 & 338.21 & Chi-Square & 40.01 \\
\hline & $\mathrm{CoN}$ & 83 & 1.71 & 0.64 & 266.44 & $D f$ & 4 \\
\hline & LS & 132 & 1.87 & 1.01 & 285.85 & Asymp. Sig. & .000 \\
\hline & Union & 96 & 1.78 & 0.84 & 274.04 & & \\
\hline & Total & 633 & 1.99 & 0.96 & & & \\
\hline \multirow[t]{6}{*}{ Library books } & LC & 72 & 1.79 & 0.8 & 39.86 & & \\
\hline & $\mathrm{CoB}$ & - & - & - & - & Chi-Square & 48.3 \\
\hline & $\mathrm{CoN}$ & - & - & - & - & $D f$ & 1 \\
\hline & LS & 35 & 5.86 & 2.64 & 83.09 & Asymp. Sig. & .000 \\
\hline & Union & - & - & - & - & & \\
\hline & Total & 107 & 3.12 & 2.52 & & & \\
\hline
\end{tabular}




\begin{tabular}{|c|c|c|c|c|c|c|c|}
\hline \multirow[t]{6}{*}{ WiFi } & LC & 239 & 1.81 & 0.79 & 386.14 & Chi-Square & 19.14 \\
\hline & $\mathrm{CoB}$ & 149 & 1.91 & 1.58 & 344.23 & $D f$ & 4 \\
\hline & $\mathrm{CoN}$ & 86 & 1.51 & 0.7 & 319.16 & Asymp. Sig. & 0.001 \\
\hline & LS & 129 & 1.49 & 0.75 & 306.74 & & \\
\hline & Union & 96 & 1.71 & 0.87 & 354.74 & & \\
\hline & Total & 699 & 1.72 & 1.02 & & & \\
\hline \multicolumn{8}{|c|}{$\begin{array}{l}\text { Note. Respondents were instructed to only rank important ite } \\
\text { respondents responded to all items. } \\
\text { - information not gathered at this site } \\
\text { a Pairwise differences detected between LS-all sites, } p<.005 \\
\text { b Pairwise comparisons detected between CoN-Union/CoB, } p \\
\text { 'Pairwise comparisons detected between LS-CoB/Union, } p<\end{array}$} \\
\hline
\end{tabular}

\begin{tabular}{|c|c|c|c|c|c|c|c|}
\hline \multicolumn{8}{|c|}{$\begin{array}{c}\text { TABLE } 5 \\
\text { Workspace and Ambience Satisfaction Ratings }\end{array}$} \\
\hline Feature & Site & $N$ & $M$ & SD & Mean Rank & \multicolumn{2}{|c|}{ Test Statistics } \\
\hline \multirow[t]{6}{*}{ Overall satisfaction } & $\mathrm{LC}$ & 304 & 4.4 & 0.54 & 359.99 & Chi-Square & 8.22 \\
\hline & $\mathrm{CoB}$ & 191 & 4.4 & 0.66 & 391.54 & Df & 3 \\
\hline & $\mathrm{CoN}$ & 96 & 4.35 & 0.858 & 408.84 & Asymp. Sig. & $.042^{\mathrm{a}}$ \\
\hline & LS & 145 & 4.5 & 0.72 & 360.82 & & \\
\hline & Union & 114 & 4.3 & 0.65 & & & \\
\hline & Total & 754 & 4.4 & 0.62 & & & \\
\hline \multirow[t]{6}{*}{ Size of personal workspace } & $\mathrm{LC}$ & 308 & 4.28 & 0.73 & 408.98 & Chi-Square & 15.82 \\
\hline & $\mathrm{CoB}$ & 197 & 4.38 & 0.834 & 463.08 & $D f$ & 4 \\
\hline & $\mathrm{CoN}$ & 102 & 4.32 & 0.869 & 446.77 & Asymp. Sig. & $.003^{b}$ \\
\hline & LS & 159 & 4.49 & 0.745 & 493.56 & & \\
\hline & Union & 123 & 4.33 & 0.83 & 441.98 & & \\
\hline & Total & 889 & 4.35 & 0.79 & & & \\
\hline \multirow[t]{6}{*}{ Overall aesthetics } & LC & - & - & - & - & Chi-Square & 21.314 \\
\hline & $\mathrm{CoB}$ & 197 & 4.43 & 0.76 & 313.24 & $D f$ & 3 \\
\hline & $\mathrm{CoN}$ & 101 & 4.46 & 0.79 & 319.76 & Asymp. Sig. & $.000^{c}$ \\
\hline & LS & 157 & 4.03 & 1.01 & 250.48 & & \\
\hline & Union & 120 & 4.14 & 0.98 & 268.92 & & \\
\hline & Total & 575 & 4.27 & 0.91 & & & \\
\hline \multirow[t]{6}{*}{ Noise privacy } & LC & - & - & - & - & Chi-Square & 15.66 \\
\hline & $\mathrm{CoB}$ & 194 & 3.93 & 1.06 & 313.51 & $D f$ & 3 \\
\hline & $\mathrm{CoN}$ & 100 & 3.5 & 1.3 & 263.12 & Asymp. Sig. & 0.001 \\
\hline & LS & 151 & 3.7 & 1.23 & 286.07 & & \\
\hline & Union & 120 & 3.49 & 1.03 & 246.38 & & \\
\hline & Total & 565 & 3.7 & 1.16 & & & \\
\hline
\end{tabular}




\begin{tabular}{|c|c|c|c|c|c|c|c|}
\hline \multirow[t]{6}{*}{ Overall noise level } & LC & & & & 427.47 & Chi-Square & 29.41 \\
\hline & $\mathrm{CoB}$ & 194 & 4.05 & 0.94 & 454.99 & Df & 4 \\
\hline & $\mathrm{CoN}$ & 100 & 3.72 & 1.3 & 408.99 & Asymp. Sig. & 0.001 \\
\hline & LS & 150 & 4.22 & 0.904 & 504.14 & & \\
\hline & Union & 120 & 3.62 & 1.09 & 357.06 & & \\
\hline & Total & 869 & 3.95 & 0.998 & & & \\
\hline \multirow[t]{6}{*}{ Visual privacy } & LC & 一 & - & 一 & - & Chi-Square & 5.2 \\
\hline & $\mathrm{CoB}$ & 194 & 3.93 & 1.02 & 295.49 & $D f$ & 3 \\
\hline & $\mathrm{CoN}$ & 100 & 3.61 & 1.3 & 261.87 & Asymp. Sig. & 0.158 \\
\hline & LS & 150 & 3.87 & 1.16 & 293.03 & & \\
\hline & Union & 120 & 3.71 & 1.1 & 265.52 & & \\
\hline & Total & 564 & 3.81 & 1.13 & & & \\
\hline $\begin{array}{l}\text { - information not } \\
\text { a No significant pair } \\
\text { b Pairwise difference } \\
\text { 'Pairwise compariso } \\
\text { c Pairwise compariso }\end{array}$ & $\begin{array}{l}\text { this site } \\
\text { nces de } \\
\text { betwee } \\
d \text { betwe } \\
\text { d betwe }\end{array}$ & $\begin{array}{l}\text { cted } \\
\text { LS-LC } \\
\text { n LS-C } \\
\text { n LS-C }\end{array}$ & $\begin{array}{l}\text { etwee } \\
p=.00 \\
\text { oN/Co } \\
\text { oB/Un }\end{array}$ & $\begin{array}{l}\text { sites, } p \\
p<.05 \\
n, p<\text {. }\end{array}$ & & & \\
\hline
\end{tabular}

TABLE 6

Students' Agreement with Needs Fulfillment

\begin{tabular}{|c|c|c|c|c|c|c|c|}
\hline \multirow{3}{*}{$\begin{array}{l}\begin{array}{l}\text { Agreement } \\
\text { Statement }\end{array} \\
\text { This space helps me } \\
\text { achieve my goals }\end{array}$} & \multirow{2}{*}{\begin{tabular}{|l|} 
Site \\
CoB \\
\end{tabular}} & \multirow{2}{*}{\begin{tabular}{c|}
$\boldsymbol{N}$ \\
189
\end{tabular}} & \multirow{2}{*}{$\begin{array}{c}M \\
4.52\end{array}$} & \multirow{2}{*}{$\begin{array}{l}\text { SD } \\
0.7\end{array}$} & \multirow{2}{*}{$\begin{array}{c}\text { Mean Rank } \\
226.27\end{array}$} & \multicolumn{2}{|c|}{ Test Statistics } \\
\hline & & & & & & Chi-Square & 1.75 \\
\hline & CoN & 96 & 4.44 & 0.89 & 231.14 & $D f$ & 2 \\
\hline & LS & 145 & 4.6 & 0.53 & 213.12 & Asymp. Sig. & 0.416 \\
\hline & Union & 114 & 4.5 & 0.73 & & & \\
\hline & Total & 448 & 4.53 & 0.66 & & & \\
\hline \multirow{5}{*}{$\begin{array}{l}\text { I feel connected } \\
\text { to my peers in this } \\
\text { space }\end{array}$} & $\mathrm{CoB}$ & 190 & 4.24 & 0.96 & 249.7 & Chi-Square & 21.18 \\
\hline & $\mathrm{CoN}$ & 96 & 4.24 & 1.09 & 188.34 & Df & 2 \\
\hline & LS & 145 & 3.8 & 1.05 & 230.46 & Asymp. Sig. & $.000^{\mathrm{a}}$ \\
\hline & Union & 114 & 4.2 & 0.76 & & & \\
\hline & Total & 449 & 4.08 & 0.97 & & & \\
\hline \multirow{5}{*}{$\begin{array}{l}\text { I feel as though I am } \\
\text { welcome in this } \\
\text { space }\end{array}$} & $\mathrm{CoB}$ & 190 & 4.59 & 0.76 & 235.33 & Chi-Square & 3.31 \\
\hline & $\mathrm{CoN}$ & 95 & 4.5 & 0.95 & 214.12 & $D f$ & 2 \\
\hline & LS & 145 & 4.5 & 0.81 & 221.62 & Asymp. Sig. & 0.191 \\
\hline & Union & 114 & 4.5 & 0.67 & & & \\
\hline & Total & 449 & 4.5 & 0.76 & & & \\
\hline \multirow{5}{*}{$\begin{array}{l}\text { This space helps me } \\
\text { focus on my task }\end{array}$} & $\mathrm{CoB}$ & 189 & 4.48 & 0.76 & 226.94 & Chi-Square & 10.74 \\
\hline & CoN & 95 & 4.31 & 1.05 & 242.98 & $D f$ & 2 \\
\hline & LS & 145 & 4.6 & 0.6 & 196.95 & Asymp. Sig. & $.005^{b}$ \\
\hline & Union & 114 & 4.3 & 0.93 & & & \\
\hline & Total & 448 & 4.5 & 0.77 & & & \\
\hline
\end{tabular}




\begin{tabular}{|c|c|c|c|c|c|c|c|}
\hline \multirow{5}{*}{$\begin{array}{l}\text { I feel safe in this } \\
\text { space }\end{array}$} & $\mathrm{CoB}$ & 191 & 4.73 & 0.58 & 226.35 & Chi-Square & 3.41 \\
\hline & $\mathrm{CoN}$ & 96 & 4.68 & 0.72 & 234.43 & Df & 2 \\
\hline & LS & 145 & 4.8 & 0.52 & 212.71 & Asymp. Sig. & 0.182 \\
\hline & Union & 114 & 4.7 & 0.65 & & & \\
\hline & Total & 450 & 4.7 & 0.58 & & & \\
\hline \multirow{6}{*}{$\begin{array}{l}\text { This space supports } \\
\text { my ability } \\
\text { to complete task }\end{array}$} & LC & 304 & 4.2 & 0.78 & 377.63 & Chi-Square & 3.19 \\
\hline & $\mathrm{CoB}$ & 191 & 4.2 & 0.79 & 382.77 & Df & 3 \\
\hline & $\mathrm{CoN}$ & 96 & 4.25 & 0.834 & 392.57 & Asymp. Sig. & 0.363 \\
\hline & LS & 145 & 4.3 & 0.74 & 349.16 & & \\
\hline & Union & 114 & 4.09 & 0.79 & & & \\
\hline & Total & 754 & 4.2 & 0.78 & & & \\
\hline \multicolumn{8}{|c|}{$\begin{array}{l}\text { Note. Likert-type scale } 1 \text { most important to } 5 \text { least important. } \\
\text { a Pairwise differences detected between LS-all sites, } p<.05 \\
\text { b Pairwise differences detected between Union-LS, } p=.007\end{array}$} \\
\hline
\end{tabular}




\section{APPENDIX D}

\section{Focus Group Semistructured Interview Script}

Question 1. Introductions and learning needs.

Please introduce yourself.

$\square \quad$ What is your major and class standing?

$\square$ How many classes are you taking?

$\square$ Do you live on or off campus?

$\square$ Do you work?

Tell us about your study habits.

$\square \quad$ How much time do you spend studying?

$\square \quad$ Where do you spend most of your time studying?

$\square \quad$ Of everywhere you could go to study, why is this your "go-to learning place"?

$\square \quad$ [if they mention multiple study spots, ask them to explain why; perhaps they use different spaces for different tasks]

Question 2. Overall satisfaction and space.

[if they don't mention current building as a main study space, shift them toward talking about it]

$\square$ What would you say are the best and worst aspects of this building?

$\square \quad$ Is there anything you wish you could do or do better while you were here that you can't?

$\square$ When asked to rank their needs for completing that day's task, students ranked Accomplishment as the most important, and Safety (freedom from harassment or unwanted attention) as the least important. From the list in front of you, how important are these to you in regard to choosing your work/study space, and how well do the spaces in this building satisfy each of these?

Question 3. Independent vs. group study needs.

$\square$ When you are studying by yourself, what environmental and space needs do you have? Do you prefer being alone, or with people you know?

$\square$ How well does this building support your needs for independent study?

$\square$ How often do you work on group projects? Is it easy to collaborate with others when you work here? Is there anything that makes it challenging to conduct group work?

\section{Question 4. Preliminary findings.}

In our survey, we asked students to identify what they were working on that day. Most respondents stated they were working on coursework alone. Additionally, students ranked noise privacy and a quiet atmosphere as the most important ambiance features for their productivity, and many made comments desiring more quiet study spaces.

$\square \quad$ This building seems very dedicated to collaborative learning spaces - are there ways the spaces could be improved to better support individual learning? Should those

\section{Question 5.} desiring quiet go somewhere else for this type of atmosphere?

Finally, are there any additional comments or observations you would like to make about the specific building?

\section{Notes}

1. Vickie Marre Karasic, "From Commons to Classroom: The Evolution of Learning Spaces in Academic 
Libraries," Journal of Learning Spaces 5, no. 2 (2016): 53.

2. Scott Bennett, "Putting Learning into Library Planning," portal: Libraries and the Academy 15, no. 2 (March 31, 2015): 215-31, https://doi.org/10.1353/pla.2015.0014.

3. Graham Walton and Graham Matthews, Exploring Informal Learning Space in the University: A Collaborative Approach (New York, NY: Routledge, 2018), 3.

4. Ieda M. Santos, Nagla Ali, and Anthony Hill, "Students as Co-Designers of a Virtual Learning Commons: Results of a Collaborative Action Research Study," Journal of Academic Librarianship 16 (2016): 7.

5. Deborah Harrop and Bea Turpin, "A Study Exploring Learners' Informal Learning Space Behaviors, Attitudes, and Preferences," New Review of Academic Librarianship 19, no. 1 (January 2013): 155, https://doi.org/10.10 80/13614533.2013.740961.

6. Bennett, "Putting Learning into Library Planning"; Andrew M. Cox, "Space and Embodiment in Informal Learning," Higher Education 75, no. 6 (June 1, 2018): 1077-90, https://doi.org/10.1007/s10734-017-0186-1; Matthew Cunningham and Graham Walton, "Informal Learning Spaces (ILS) in University Libraries and Their Campuses: A Loughborough University Case Study," New Library World 117, no. 1/2 (January 11, 2016): 49-62, https://doi. org/10.1108/NLW-04-2015-0031; Romana Martin and Tania Broadley, "Building New Informal Learning Spaces: Mini Case Studies," in Exploring Informal Learning Space in the University: A Collaborative Approach, eds. G. Walton and G. Matthews (New York, NY: Routledge, 2018), 75-90; Angela Christy, Sonia Tampubolon, and Hanson E. Kusuma, "Campus' Informal Learning Spaces for Reading Activities and Their Relation to Undergraduates' Responses," DIMENSI (Journal of Architecture and Built Environment) 46, no. 2 (February 28, 2020): 117-28, https:// doi.org/10.9744/dimensi.46.2.117-128.

7. Barbara Blummer and Jeffrey M. Kenton, "Learning Commons in Academic Libraries: Discussing Themes in the Literature from 2001 to the Present," New Review of Academic Librarianship 23, no. 4 (October 2, 2017): 329-52, https://doi.org/10.1080/13614533.2017.1366925.

8. Naomi Berman, "A Critical Examination of Informal Learning Spaces," Higher Education Research $\mathcal{E}$ Development 39, no. 1 (January 2, 2020): 127-40, https://doi.org/10.1080/07294360.2019.1670147; Jos Boys, Towards Creative Learning Spaces: Re-Thinking the Architecture of Post-Compulsory Education (Milton Park, UK: Routledge, 2010); Qi Deng et al., "The Role of the Library Café as a Learning Space: A Comparative Analysis of Three Universities," Journal of Librarianship and Information Science (December 11, 2017), 0961000617742469, https://doi. org/10.1177/0961000617742469.

9. E.E. Bennett, "Informal Adult Learning in Simulated and Virtual Environments," in Encyclopedia of Information Communication Technologies and Adult Education Integration (2010), 838-56, https://doi.org/10.4018/9781-61692-906-0.ch051.

10. Emily Altimare and David M. Sheridan, "The Role of Nonclassroom Spaces in Living-Learning Communities," Journal of Learning Spaces 5, no. 2 (2016): 14.

11. Monique Boekaerts and Alexander Minnaert, "Self-Regulation with Respect to Informal Learning," International Journal of Educational Research 31, no. 6 (January 1, 1999): 533-44, https://doi.org/10.1016/S08830355(99)00020-8.

12. Scott Bennett, "Learning Behaviors and Learning Spaces," portal: Libraries and the Academy 11, no. 3 (2011): 765-89.

13. Stephen R. Acker and Michael D. Miller, "Campus Learning Spaces: Investing in How Students Learn," n.d., 11; Diana Oblinger, "Space as a Change Agent," in Learning Spaces (EDUCAUSE, 2006), 1.1-1.4.

14. Deeann Allison et al., "Academic Library as Learning Space and as Collection: A Learning Commons' Effects on Collections and Related Resources and Services," Journal of Academic Librarianship 45, no. 3 (May 2019): 305-14, https://doi.org/10.1016/j.acalib.2019.04.004.

15. Alison J. Head, "Planning and Designing Academic Library Learning Spaces: Expert Perspectives of Architects, Librarians, and Library Consultants. Project Information Literacy Research Report. The Practitioner Series." Project Information Literacy Research Report. The Practitioner Series. Project Information Literacy, December 6, 2016.

16. Giovanna Badia, "More Data Collection $\neq$ More Valid Results: A Critical Review of Space Assessment Methods in Academic Libraries," New Review of Academic Librarianship 0, no. ja (June 30, 2020): 1-17, https://doi.or g/10.1080/13614533.2020.1777575; Studying Students: The Undergraduate Research Project at the University of Rochester, eds. Nancy Fried Foster and Susan Gibbons (Chicago, IL: Association of College and Research Libraries, 2007); Bryony Ramsden, "Ethnographic Methods in Academic Libraries: A Review," New Review of Academic Librarianship 22, no. 4 (October 1, 2016): 355-69, https://doi.org/10.1080/13614533.2016.1231696.

17. Seung Hyun Cha and Tae Wan Kim, "The Role of Space Attributes in Space-Choice Behaviour and Satisfaction in an Academic Library," Journal of Librarianship and Information Science 52, no. 2 (2020): 399-409; Alison Cotgrave and Hannah Kira Wilson, "Factors That Influence Students' Satisfaction with Their Physical Learning 
Environments," Structural Survey 34, no. 3 (July 11, 2016): 256-75, https://doi.org/10.1108/SS-01-2016-0004; Erica DeFrain and Miyoung Hong, "Interiors, Affect, and Use: How Does an Academic Library's Learning Commons Support Students' Needs?" Evidence Based Library and Information Practice 15, no. 2 (June 15, 2020): 42-68, https:// doi.org/10.18438/eblip29677; Sara Holder and Jessica Lange, "Looking and Listening: A Mixed-Methods Study of Space Use and User Satisfaction," Evidence Based Library and Information Practice 9, no. 3 (2014): 4-27.

18. Esther M.W. Woo, Alexander Serenko, and Samuel K.W. Chu, "An Exploratory Study of the Relationship between the Use of the Learning Commons and Students' Perceived Learning Outcomes," Journal of Academic Librarianship 45, no. 4 (July 1, 2019): 413-19, https://doi.org/10.1016/j.acalib.2019.05.007.

19. Walton and Matthews, Exploring Informal Learning Space in the University, 146.

20. Badia, "More Data Collection $\neq$ More Valid Results."

21. Bennett, "Putting Learning into Library Planning"; Oblinger, "Space as a Change Agent."

22. Susan Gardner Archambault and Alexander Justice, "Student Use of the Information Commons: An Exploration through Mixed Methods," Evidence Based Library and Information Practice 12, no. 4 (December 30, 2017): 13-40, https://doi.org/10.18438/B8VD45; Robert James, "Culture War in the Collaborative Learning Center," Journal of Learning Spaces 2, no. 1 (2013): 9; Megan A. Jaskowiak et al., "We're All in This Together: An Examination of Seating and Space Usage in a Renovated Academic Library," Library Philosophy and Practice (2019): 18, https:// digitalcommons.unl.edu/cgi/viewcontent.cgi?article=6483\&context=libphilprac.

23. Michael J. Whitchurch, "Evaluating Group Use of the Information Commons," College \& Undergraduate Libraries 16, no. 1 (January 2009): 71-82, https://doi.org/10.1080/10691310902754130; Brittney Thomas et al., "The Design and Assessment of the Learning Commons at the University of Iowa," Journal of Academic Librarianship 41, no. 6 (November 1, 2015): 804-13, https://doi.org/10.1016/j.acalib.2015.09.005; EunYoung Yoo-Lee, Tae Heon Lee, and LaTesha Velez, "Planning Library Spaces and Services for Millennials: An Evidence-based Approach," Library Management 34, no. 6/7 (August 9, 2013), https://doi.org/10.1108/LM-08-2012-0049.

24. Francine May and Alice Swabey, "Using and Experiencing the Academic Library: A Multisite Observational Study of Space and Place," College E Research Libraries 76, no. 6 (2015), https://doi.org/10.5860/crl.76.6.771; Priya Mehta and Andrew Cox, "At Home in the Academic Library? A Study of Student Feelings of 'Homeness,'” New Review of Academic Librarianship, 2019, 1-34; Mariana Regalado and Maura A. Smale, "I Am More Productive in the Library Because It's Quiet': Commuter Students in the College Library," College \& Research Libraries 76, no. 7 (November 1, 2015): 899-913, https://doi.org/10.5860/crl.76.7.899; Silas M. Oliveira, "Space Preference at James White Library: What Students Really Want," Journal of Academic Librarianship 42, no. 4 (July 2016): 355-67.

25. Badia, "More Data Collection $\neq$ More Valid Results."

26. Badia, "More Data Collection $\neq$ More Valid Results," 16.

27. Berman, "A Critical Examination of Informal Learning Spaces."

28. Berman, "A Critical Examination of Informal Learning Spaces," 137.

29. Bennett, "Learning Behaviors and Learning Spaces," 778.

30. Deng et al., "The Role of the Library Café as a Learning Space"; Jonathan Hunter and Andrew Cox, "Learning over Tea! Studying in Informal Learning Spaces," New Library World 115, no. 1/2 (January 7, 2014): 34-50, https://doi.org/10.1108/NLW-08-2013-0063; Christy, Tampubolon, and Kusuma, "Campus' Informal Learning Spaces for Reading Activities and Their Relation to Undergraduates' Responses"; Cunningham and Walton, "Informal Learning Spaces (ILS) in University Libraries and Their Campuses."

31. May and Swabey, "Using and Experiencing the Academic Library."

32. Cunningham and Walton, "Informal Learning Spaces (ILS) in University Libraries and Their Campuses."

33. Hunter and Cox, "Learning over Tea! Studying in Informal Learning Spaces," 47.

34. Deng et al., "The Role of the Library Café as a Learning Space," 16.

35. Craig Deed and Scott Alterator, "Informal Learning Spaces and Their Impact on Learning in Higher Education: Framing New Narratives of Participation," Journal of Learning Spaces 6, no. 3 (2017): 56.

36. John W. Creswell et al., "Advanced Mixed Methods Research Designs," Handbook of Mixed Methods in Social and Behavioral Research 209 (2003): 240.

37. Deed and Alterator, "Informal Learning Spaces and Their Impact on Learning in Higher Education," 56.

38. Danuta A. Nitecki and Katherine Simpson, "Communicating the Library as a Learning Environment," n.d., 14.

39. Woo, Serenko, and Chu, "An Exploratory Study of the Relationship between the Use of the Learning Commons and Students' Perceived Learning Outcomes," 413-19.

40. Michael Quinn Patton, Qualitative Research \& Evaluation Methods: Integrating Theory and Practice, 4th ed. (Thousand Oaks, CA: Sage Publications, 2015), 281.

41. DeFrain and Hong, "Interiors, Affect, and Use."

42. Lisa M. Given and Heather Archibald, "Visual Traffic Sweeps (VTS): A Research Method for Mapping 
User Activities in the Library Space," Library \& Information Science Research 37, no. 2 (April 1, 2015): 100-08, https:// doi.org/10.1016/j.lisr.2015.02.005.

43. Lisa M. Given and Gloria J. Leckie, "'Sweeping' the Library: Mapping the Social Activity Space of the Public Library," Library \& Information Science Research 25, no. 4 (December 2003): 365-85, https://doi.org/10.1016/ S0740-8188(03)00049-5.

44. Wolfgang F.E. Preiser, Harvey Z. Rabinowitz, and Edward T. White, Post-Occupancy Evaluation: Routledge Revivals (Milton Park, UK: Routledge, 2015).

45. Bennett, "Learning Behaviors and Learning Spaces"; Bennett, "Putting Learning into Library Planning." 46. Woo, Serenko, and Chu, "An Exploratory Study of the Relationship between the Use of the Learning Commons and Students' Perceived Learning Outcomes."

47. Virginia Braun and Victoria Clarke, "Using Thematic Analysis in Psychology," Qualitative Research in Psychology 3, no. 2 (January 2006): 77-101, https://doi.org/10.1191/1478088706qp063oa.

48. James, "Culture War in the Collaborative Learning Center"; Michael J. Khoo et al., "'A Really Nice Spot': Evaluating Place, Space, and Technology in Academic Libraries," College \& Research Libraries 77, no. 1 (2016): 51-70, https://doi.org/10.5860/crl.77.1.51.

49. Office of Institutional Effectiveness and Analytics, "Fact Book 2018-2019" (Lincoln, NE: University of Nebraska-Lincoln, 2018), https://iea.unl.edu/publications/fb18_19.pdf.

50. Studying Students: The Undergraduate Research Project at the University of Rochester, eds. Nancy Fried Foster and Susan Gibbons (Chicago, IL: Association of College and Research Libraries, 2007).

51. May and Swabey, "Using and Experiencing the Academic Library."

52. Boekaerts and Minnaert, "Self-Regulation with Respect to Informal Learning."

53. Berman, "A Critical Examination of Informal Learning Spaces."

54. Bennett, "Learning Behaviors and Learning Spaces." 